\title{
Sebîlürreşâd Muharriri S.M. (Seyyid Muhammed) Tevfik Külliyatına Methal
}

\author{
Ekrem Saltık \\ (ORCID: 0000-0001-8087-0986) \\ Makale Gönderim Tarihi \\ 05.09.2020 \\ Makale Kabul Tarihi \\ 25.03.2021
}

\section{Atıf Bilgisi/Reference Information}

Chicago: Saltık, E., "Sebîlürreşâd Muharriri S.M. (Seyyid Muhammed) Tevfik Külliyatına Methal”, Vakanüvis-Ulus/ararası Tarih Araştırmaları Dergisi, 6/1 (2021): 312-348.

APA: Saltık, E. (2021). Sebîlürreşâd Muharriri S.M. (Seyyid Muhammed) Tevfik Külliyatına Methal. Vakanüvis-Uluslararası Tarih Araştırmaları Dergisi, 6 (1) , 312-348.

Öz

Osmanlı matbuat tarihi ve İslamcı dergiler literatürünün en önemli yayınlarından biri olan Sebîlürreşâd dergisi, aynı zamanda dönemin düşünce hayatına yön veren üretken muharrirleriyle de öne çıkan uzun soluklu bir dergidir. Kadrosunda, yaşamı ve entelektüel üretimleri ortada olan ünlü muharrirler olduğu kadar, yaşamı ve yazdıklarına dair herhangi bir çalışma yapılmamış muharrirler de bulunan Sebîlürreşâd'ın, yaşam hikâyesi ve yazını araştırımamıs olan muharrirleri arasında S.M. Tevfik de bulunmaktadır. Literatürde genellikle Sebîlürreşâd dergisinde Hindistan Mektupları adıyla yayınladığı makaleleriyle bilinen S.M. Tevfik, aslında hem II. Meşrutiyet Dönemi Türkçe matbuatı hem de eş zamanlı olarak İstanbul merkezli yayın yapan Farsça matbuatı açısından önemli olan aksiyoner bir gazetecidir. Osmanlı matbuatındaki görünürlüğünün ortadan kaybolduğu dönemin üzerinden geçen bir asırdan sonra yapılan yeni araştırmalarda, aslında muharrirlik kariyerinin sadece Sebîlürreşâd ya da ilgili literatürde oldukça sık atıf yapılan Hindistan Mektupları'ndan ibaret olmadığı anlaşılan S.M. Tevfik'in şimdiye kadar

\footnotetext{
* Dr. Öğr. Üyesi, İstinye Üniversitesi, Fen-Edebiyat Fakültesi, Sosyoloji Bölümü, Türkiye, esaltik@istinye.edu.tr.
}

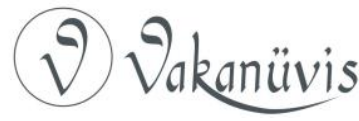


karanlıkta kalmış yaşamı kadar bu yaşamı adarcasına ortaya koyduğu zengin külliyat da oldukça önemlidir. Bu makale, çeşitli yazılarında S.M.T. [. [. م. ت] ve ve S.M. Tevfik [س. م. ق م ف فوت] imzaları kullanan, tam adıyla Seyyid Muhammed Tevfik Hemedanî́nin II. Meşrutiyet Döneminin çeşitli süreli yayınlarındaki yüzlerce makalesi ve muhtevaları bakımından oldukça ilginç olan özgün kitaplarından oluşan külliyatına dair müstakil bir bibliyografya oluşturmak üzere kaleme alınmıştır.

Anahtar Kelimeler: Hemedanî, S.M.T., Seyyid Muhammed Tevfik, Hindistan Mektupları, Sebîlürreşâd, Şehbâl, Cerîde-i Sûfiyye

\title{
An Introduction to the Works of Sebîlürreşâd Reporter S.M. (Sayyid Muhammad) Tawfiq
}

\begin{abstract}
Sebîlürreşâd, one of the most important publications of the Ottoman printing history and Islamist literary magazines, is also a long-standing journal that stands out with its productive writers who shaped the intellectual life of the period. The staff of Sebîlürreşâd consisted not only of reporters whose life and intellectual productions have been studied but also those whose life and literary works have remained unrevealed. S.M. Tawfiq is among the latter. In the literature, S.M. Tawfiq, who is known for his articles published mainly in the Sebîlürreşâd journal under the heading Letters from India was actually an active journalist who is important in terms of the II. Constitutional era Turkish press as well as the Farsi press which published simultaneously in Istanbul. In new studies carried out over a century after the period in which the visibility of the Ottoman press disappeared, light has been shed on S.M. Tawfiq's life which has remained in the dark until now to reveal that his career was not limited to Sebîlürreşâd or Letters from India which have been frequently cited in the related literature but includes an important rich collection that he has devoted his life to. This article has been prepared to establish an independent bibliography for the various articles of the reporter whose full name was Sayyid Muhammad Tawfiq Hemedanî and who used the signatures of S.M.T. [. م. م. ت and S.M. Tawfiq [س. م. ق مي فوت] to sign his hundreds of articles which were published in various periodicals of the II. Constitutional era and his original books, the contents of which are very interesting.
\end{abstract}

Keywords: Hemedanî, S.M.T., Sayyid Muhammad Tawfiq, Letters of India, Sebîlürreşâd, Şehbâl, Cerîde-i Sûfiyye

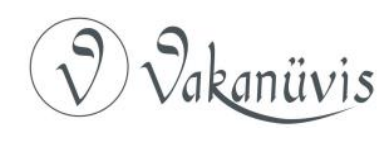




\section{Giriş}

Osmanlı basın tarihi ve II. Meşrutiyet Döneminin İslamcı matbuat özelinde öne çıkan önemli süreli yayınlarından biri olan Sebîlürreşâd dergisinin okuyucu kitlesi, yayın hayatına başlamasından bir süre sonra Anadolu sınırlarını aşarak, Rusya'dan Orta Asya'ya, Güney Asya'dan Uzakdoğu'ya kadar uzayan geniş bir coğrafyaya ulaşmıştır. Derginin kısa sürede böylesine geniş bir okuyucu kitlesine ulaşmış olması, hiç şüphesiz zengin içeriğinin yanı sıra yazar çeşitliliğiyle de ilişkilidir. "İslâm âleminin uyanması ve yükselmesi için çalışmayı en mukaddes görev kabul eden" derginin bu misyonuna katkı sağlayan bazı yazarların, birer "fikir işçisi" olarak başka mecralarda ürettikleri literatür pek fazla irdelenmemiştir. Benzer şekilde, dergide özgün imzalarla yer alan bazı yazarların birer "kalem ve kelam erbabı" olmalarının dışında, gerçekte kim oldukları da bilinmemektedir. Bu bağlamda sahayla ilgili çalışmalarda adına sık sık atıf yapılan Sebîlürreşâd yazarlarından olmasına rağmen, gerçekte kim olduğu ve Sebîlürreşâd öncesi ve sonrasında nasıl bir yaşam sürdürdüğü gözden kaçırılmış olan önemli isimlerden birisi de dergide yayınladığı Hindistan Mektupları'yla bilinen S.M. Tevfik olmuştur. Tevfik Bey'in bilinmeyen yaşamının bir parçası olan Hindistan Mektupları'na atıf yapılan bazı çalışmalarda, kimliğiyle ilgili kullanılan "meçhul" ifadesi, yaşamının yanı sıra, Hindistan Mektupları dışında kalan yazıları için de geçerlidir. Zira kendisinden birkaç cümleyle bahseden sınırlı sayıdaki çalışmada, bir şekilde peşinen "üretken" bir muharrir olarak tarif edilen Tevfik Bey'in, Sebîlürreşâd dergisindeki Hindistan Mektupları dışında kalan yazınına dair de herhangi bir çalışma yapılmamıştır. Oysa söz konusu muharririn Osmanlı matbuatındaki görünürlüğünün kayboluşundan bir asır sonra gerçekleştirilen uzun soluklu araştırmaların neticesinde yazılan, "Sebîlürreşâd'ın Hindistan Muhâbiri S.M. Tevfik'in 'Meçhul' Biyografisine Dair" ve "Bir Gazetecinin 'Muhibban-ı Kütüb' Olarak Portresi ve S.M. Tevfik Kütüphanesi" adlı öncü çalışmaların ortaya koyduğu üzere, S.M. Tevfik, II. Meşrutiyet Döneminin siyasi atmosferinde, Osmanlı Devleti ve İslam dünyasının içinde bulunduğu durumdan çıkabilmesi için fikir üreten, üstelik bu amaçla bizzat sahaya inen bir aksiyoner olmasına rağmen, çeşitli sebeplerle gözden kaçırılmış önemli bir muharrirdir. Üstelik Tevfik Bey'in gazetecilik faaliyetleri, sadece Türkçe Osmanlı matbuatı açısından değil, 20. yüzyılın başında İran'daki meşrutiyet hareketine yön

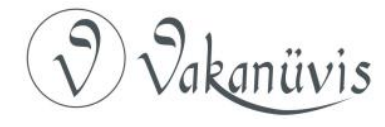


veren entelektüel hareket bağlamında dönemin Farsça matbuatı, dolayısıyla Osmanlı Devleti'nin sınırlarını aşan geniş bir siyasi ve kültürel coğrafya açısından da önemlidir. Dolayısıyla Tevfik Bey'in karanlıkta kalan yaşamının tüm yönleriyle aydınlatılması kadar, bir gazeteci ve muharrir olarak yaşamı boyunca ürettiği yazının ortaya konulması da hem dönemin İslamcı matbuatına dâhil olan isimlerin birbirleriyle kurdukları temaslar ve bu temasların dönemin düşünce akımlarındaki domino etkisinin anlaşılması hem de kolektif amaçlarla ortaya koydukları literatürün tüm yönleriyle anlaşımasına büyük katkı sağlayacaktır. Bu gerekçelerle kaleme alınan bu makale, yapılan araştırmalar neticesinde, yaşamı boyunca II. Meşrutiyet Döneminin çeşitli gazete ve dergilerinde yayınlanan yüzlerce makale ve muhtevaları bakımından oldukça ilginç olan çeşitli kitaplar yazdığı anlaşılan Tevfik Bey'e ait Türkçe külliyatın bir araya getirildiği müstakil bir bibliyografya oluşturmak üzere kaleme alınmıştır. Bu sayede özellikle 20. yüzyılın ilk çeyreği boyunca yazdıklarıyla Osmanlı matbuat tarihi açısından önemli bir profil çizen S.M. Tevfik'in Türkçenin yanı sıra Farsça, İngilizce ve Urduca başta olmak üzere -muhtemel - farklı dillerde, dağınık halde bulunan diğer yazılarının fark edilerek gün yüzüne çıkarılması, Türkçe yazılarında kullandığı "mütevazi" imzalarıyla ilişkilendirilebilmesi ve nihayet yaşamının karanlıkta kalan kısımlarının aydınlatılmasına katkı sağlanması hedeflenmektedir.

\section{Meşrutiyet Dönemi Matbuatında Tevfik Bey}

İsfahanlı bir baba ve Iraklı bir annenin çocuğu olarak Hindistan'da doğup, İstanbul'da büyüyen ve eğitimini Bağdad Mekteb-i İdadisinde tamamlayan $^{1}$ S.M. Tevfik'in tam adı, Seyyid Muhammed Tevfik Hemedanî́dir. İranlı bir babanın çocuğu olsa da annesinden dolayı Osmanlı tebaasından olan S.M. Tevfik, Osmanlı matbuat tarihine Sebîlürreşâd dergisindeki yazılarıyla dâhil olmuş ve 1912 yılından itibaren yazı işleri heyetinde yer aldığı bu dergide, S.M.T. [. م. م. ت. S.M. Tevfik [س. م. ق قي فوت] imzalarıyla yayınladığı yazılarını, 1920 yılına kadar sürdürmüştür.

Tevfik Bey, Sebîlürreşâd dergisi yazı heyetine dâhil olmasından evvel, sadece II. Meşrutiyet Dönemi Türkçe Osmanlı matbuatı açısından değil,

${ }^{1}$ BOA, ZB. 104/36-0

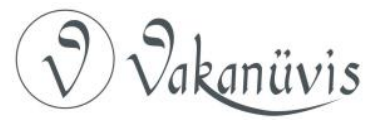


eş zamanlı olarak İran Meşrutiyeti ve matbuat tarihi açısından da önemli bir isim olmasını sağlayacak bir kariyer çizgisi izlemiş, 1900'lerin hemen başında İstanbul'da yayınlanan Şems ve Süruş gibi Farsça gazetelerin yazar ve editör kadrosunda yer almıştır. ${ }^{2}$

İran'daki Meşrutiyet Hareketini yurt dışından destekleyen İstanbul merkezli İran diasporasının mensubu olduğu anlaşılan Tevfik Bey, ayrıca İstanbul merkezli bir başka Farsça gazete olan Hâver gazetesini de uzun yıllar yönetmiş, bu gazetedeki rolü ve yayın politikalarıyla, II. Meşrutiyet Dönemi İran matbuatındaki önemli rolünü pekiştirmiştir. 20. Yüzyılın hemen başında bir nevi tüm Avrupa'daki muhalefete de yön veren İstanbul'daki meşrutiyetçi İranlı entelektüellerin dâhliyle İstanbul'da yayınlanan Şems ve Surûş gazetelerinden sonra Sebîlürreşâd muhabiri olarak yaptığı Hindistan seyahatinin tamamlandığı sıralarda yayınlamaya başladığı Hâver gazetesindeki yazılarını, Sebîlürreşâd dergisindeki yazılarıyla eş zamanlı olarak sürdürmüş olan Tevfik Bey, aktif olarak yer aldığı bu süreli yayınlar dışında, Şehbâl, Cerîde-i Sûfiyye ve el-Hilâl gibi dönemin diğer gazete ve dergilerinde de çeşitli makaleler yazmıştır.

Tevfik Bey'in Hindistan Mektupları'na atıf yaparken “üretken” bir gazeteci olduğuna işaret ederken hakkında parantez açma gereği duyan nadir isimlerden biri olan S.T. Wasti'nin de işaret ettiği üzere; literatürde yaşamına dair pek fazla bilgi bulunmayan S.M. Tevfik'in ${ }^{3}$, üretkenliği kabul edilse de şimdiye kadar, bu üretkenliğin dayanağı olarak detaylarıyla ortaya konulmamış olan yazın kariyeri, sadece II. Meşrutiyet Dönemi Türkçe ve Farsça matbuatındaki makalelerinden ibaret kalmamıştır. Tevfik Bey'in farklı içeriklere sahip çeşitli kitaplar da yazmış olmasının yanı sıra, kayıtlarda ayrıca "mütercim" olarak da yer almasını sağlayacak olan bir tercümesi, Türkiye Cumhuriyeti'nin kuruluşundan sonra yayınlanmıştır. Bu zeminde çalışmanın sonraki bölümlerinde, Tevfik Bey'in, yaşamı boyunca yazın alanında muhabirlikten muharrirliğe, editörlükten mütercimliğe uzanan geniş bir yelpazedeki

\footnotetext{
2 Edward Granville Browne, Press And Poetry of Modern Persia, Cambridge 1914.

3 Syed Tanvir Wasti, "The Indian Red Crescent Mission to the Balkan Wars", Middle Eastern Studies, 45:3 (2009), p.406.
}

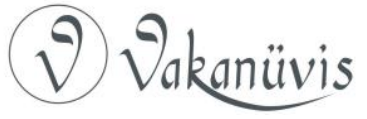


profesyonel kimlikleri ve farklı imzalarıyla yayınlanan çalışmaları sıralanacaktır.

\section{Seyyid Muhammed Tevfik Hemedanî Külliyatı}

Osmanlı ve İran matbuatındaki görünümleri, yukarıda bahsedilen çeşitli gazetelerde yayınlanan yüzlerce makalesi ve editöryal görevlerinin zenginleştirdiği kimlikleriyle ilişkili olan Seyyid Muhammed Tevfik Hemedani'nin, S.M. Tevfik yaygın adıyla Osmanlı matbuat tarihine dâhil olmasını sağlayan Sebîlürreşâd dergisinin çeşitli sayılarında, hazırlığını yaptığı kitaplara dair ipuçlarını ve ardından farklı içeriklerle yayınladığı kitapların haberlerini bulmak mümkündür. Bu bağlamda örneğin, derginin Hindistan muhabiri olarak Kolombo'da bulunduğu sırada yazdığı bir mektubunda, bölgedeki misyonerler hakkında müstakil bir kitap hazırlığı içerisinde olduğunu okuyucularıyla paylaşmış olan Tevfik Bey, İstanbul'a döndükten sonra yayınlayacağını söylediği bu kitabın, misyonerlerin faaliyetleri konusunda "mufassal $m a^{\prime}$ lûmâta" sahip olduğunu defaatle belirtmiştir. ${ }^{4}$

Seyyid Muhammed Tevfik külliyatına dâir araştırmalar sırasında Hindistan Mektupları'nda bahsini ettiği misyonerlik temalı kitabını tamamlayıp tamamlamadığı henüz anlaşılamamışsa da bu araştırmalarla, nihayet farklı kitaplarına ulaşmak mümkün olmuştur. Tevfik Bey'in kitaplarına ulaşmak için yapılan araştırmalar neticesinde keşfedilen kitaplarının, Sebîlürreşâd dergisinde bahsini ettiği misyonerlik konusunda yahut farklı fikri meselelerle ilgili olmasalar da yayınlandıkları dönem ve alfabe açısından öncülerden olabilecek ilginç, dil bilimsel içeriklere sahip olduğu görülmüştür. Tevfik Bey'in çoğunluğu Ingilizce öğrenimiyle ilgili olan bu kitaplarının, yaşamı boyunca farklı bir fikri ve entelektüel profil çizmiş olan bu çok yönlü muharririn, yabancı dil hâkimiyeti ve eğitimcilik kariyerinden beslenen bir çabanın sonucu olarak yayınlandığını söylemek mümkündür. Dil eğitimi ve öğrenimiyle ilgili olan ve künye bilgileri aşağıda sıralanan Kendi Kendine ingilizce Usûl-i Tedris kitabı gibi, İngilizce öğrenimine dair çeşitli kitaplar hazırlamış olması, Hindistan Mektupları'nda İslam dünyasında kitaplarla teşrik-i mesaisi en fazla olan ulema ve sair kişilerin "iki satırlık Arapça bir

4 S.M. Tevfik, "Madras Şehri", Sebîlürreşâd, 16 Ekim 1913, s.92; S.M. Tevfik, "Seylan Adası”, Sebîlürreşâd, 20 Kasım 1913: s.171.

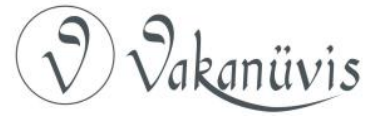


kitabı" dâhi "okuyamayışından" şikâyet etmiş olan Tevfik Bey'in, bu eleştirilerini, aslında yabancı dil hâkimiyetinin yanı sıra eğitim konusundaki uzmanlığına güvenerek yaptığını da göstermektedir.

Hindistan Mektupları'nda geçen söz konusu eleştirilerinin devamında "sırf kâğıt yığınlarıyla" uğraşmanın nafile olduğuna işaret etmiş olan Tevfik Bey'in, aynı zamanda İstanbul'daki İran diasporasının önemsediği bir eğitimci olduğu ve ortalamanın üzerindeki çoklu dil hâkimiyeti, çağdaşı olan bir diplomatın hatıralarına da yansımıştır. Bu bağlamda Tevfik Bey'in İstanbul'daki yaşamının bir dönemine şahit olan ve onunla ilgili gözlemlerimi sahip olduğu entelektüel donanıma işaret edecek şekilde dile getiren Han Melik Sasanî, İstanbul'daki İran sefaretinde görev yaptığı sırada tanıştığı Tevfik Bey'in, Türkçe ve Farsçanın yanı sıra Arapça, Hintçe ve İngilizce konuşabildiğini nakletmektedir. ${ }^{5}$ Yine Sasanî'nin verdiği bilgilere göre Tevfik Bey, 20. yüzyılın hemen başında İstanbul'da bulunan İran diasporasının eğitim faaliyetleri açısından oldukça önemli olan İran Okulu'nun [Debistân-ı Iraniyân] idareciliğini de yapmaktadır. ${ }^{6}$ Hindistan Genel Kurmayı tarafından hazırlanan Who's Who in Persia adlı biyografi antolojisinde de Debistân-ı İraniyân idarecisi olduğu belirtilen Tevfik Bey'in ${ }^{7}$ Sebîlürreşâd dergisi kadrosuna dâhil olmasından önce - sürdürdüğü eğitimle ilgili bu profesyonel deneyimi ve çoklu dil hâkimiyetini, gazetecilik dışındaki yazın faaliyetlerinin formasyonel zemini haline getirerek, Osmanlı kaligrafisiyle İngilizce öğrenimini ele alan yabancı dil öğrenimi kitaplarına dönüştürmesi, eğitim tarihi açısından da önemli ve oldukça ilgi çekicidir.

Tevfik Bey tarafından hazırlanan ve çeşitli nadir eser kataloglarında muhtemelen - S.M.T. şeklindeki "kısaltılmış", dolayısıyla "tanınması güç" bir imzayla kayıtlı olduğu için şimdiye kadar fark edilememiş olan İngilizce öğrenimine dair kitaplardan ilkinin yayınlanışı, "Sebîlürreşâd heyet-i tahrîriyyesinden S.M.T. Bey tarafından gayet mükemmel ingilizce bir elif-bâ ile iki cildden ibâret bir usûl-i tedrîs kitabı te'lîf

\footnotetext{
${ }^{5}$ Han Melik Sasanî, Payitahtın Son Yıllarında Bir Sefir, çev. Hakkı Uygur, İstanbul 2006, s.31-32.

${ }^{6}$ Sasanî, a.g.e., s.81-83.

7 "Saiyid Muhammad Tewfik, Chamberlain to Muhammed Ali Mirza", Who's Who in Persia, II, Sımla 1923, p.339.
}

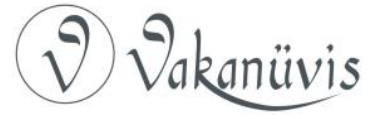


olunmuştur." cümlesiyle başlayan bir haberle, derginin Nisan 1919 tarihli nüshasına yansımıştır. Söz konusu kitabın tanıtıldığı bu haberin devamında; "Ingilizceyi taallüm etmek isteyenlerin bu usûl sâyesinde kendi kendine muallime hâcet kalmaksızın, ingilizcenin sûret-i telaffuzunu, kavâidini, tasrîfâtını, pek suhûletle öğrenebilecekleri" ifade edilmiş, nihayet iki ciltten oluştuğunu işaret edecek şekilde, "kitabın muhteviyâtı olan ingilizce kelimeleri kolaylıkla ezberleyebilmek için de ikinci cildin sonunda bin kelimeyi mütecâviz bir lügatçe" ilâve edildiği belirtilerek, bu iki ciltlik İngilizce öğrenim "setinin", "Bâbıâlî Caddesi'nde ikbâl Kütüphânesi'nden temin edilebileceği duyurulmuştur. ${ }^{8}$

S.M.T. imzasını taşıyan ve "heveskârânın te'mîn-i istifâdeleri nazar-ı dikkate alınarak" hazırlandığı ifade edilen iki ciltlik İngilizce Elifbanın arka kapağında, Tevfik Bey'in yine İngilizce öğrenimiyle ilgili olan Resimli Ingilizce Elifbâ ve Ingilizce - Türkçe Metot Birliği gibi diğer kitaplarının listesi de verilmiştir. Bu listede Resimli Ingilizce Elifbâ adıyla bulunan ve aslında 1870 'lerden başlayarak Kanada eyaletlerinde okutulan sekiz kitaplık İngilizce alfabe serisinin ilk kitabı olan The Royal School Primer adlı kitap, ${ }^{9} 1918$ yılında gerçekleştirilen yeni illüstrasyonlarla basılmış Ingilizce orijinalinin birebir mizanpajı üzerine Tevfik Bey'in Osmanlı kaligrafisiyle yaptığı bir edisyon olarak 1919 yılında ilk baskısını yapmıştır. Tevfik Bey'in Kanada'daki baskısından birkaç ay sonra Osmanlıca kaligrafiyle edite ederek yayınladığı ve okula başlayan çocukların alfabedeki harfleri tanıma ve heceleme yapmalarına yönelik bir içeriğe sahip olan bu kitap, harfleri okuma ve kelime öğrenme dersleri ve harflerden kelime oluşturmaya yönelik derslerden oluşan iki bölümden oluşmaktadır. Osmanlı coğrafyasındaki 1919 tarihli edisyonundan sonra Türkiye'deki ikinci baskısı 1924 yılında yine Tevfik Bey tarafından gerçekleştirilen The Royal School Primer adlı kitap da dâhil, Tevfik Bey'in ikkbâl Kütüphanesince yayınlanmış S.M.T. imzalı İngilizce öğrenimiyle ilgili kitaplarına ait künye bilgileri aşağıdaki gibidir;

\footnotetext{
8 “ingilizce Elifbâ ve Usûl-i Tedris”, Sebîlürreşâd, 17 Nisan 1919, s.160.

9 Dorothy Candlish Sharp, Early Childhood Programs: A Study of Provision for Kindergartem and Pre-School Programs in Newfoundland, Unpublished Masters Thesis, Newfoundland 1976, p.49-50.
}

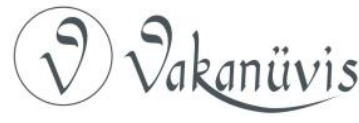




\section{Tevfik Bey’in Ingilizce Öğrenim Kitapları}

S.M.T., English Self-Taught (Kendi Kendine Ingilizce Usûl-i Tedris), C.1, İstanbul: İkbâl Kütüphânesi, 1919.

S.M.T., English Self-Taught (Kendi Kendine Ingilizce Usûl-i Tedris), C.2, İstanbul: İkbâl Kütüphânesi, 1919.

S.M.T., Ingilizce - Türkçe Metot Birliği, İstanbul: i̇kbâl Kütüphânesi, 1919.

S.M.T., The Royal School Primer, at Sublime Port N.2, Stamboul, (Hussain: Ikbal Library), Constantinople: Société Anonyme de Papeterie et d'Imprimerie, 1919.

S.M.T., The Royal School Primer, at Sublime Port N.2, Stamboul, (Hussain: Ikbal Library), Constantinople: Société Anonyme de Papeterie et d'Imprimerie, (Second Edition) 1924.

\section{Tevfik Bey'in Pırlanta Mektuplar'ı}

Hakkındaki araştırmalar sırasında aynı zamanda yaşamını hem içerikleri hem de sanatsal özellikleriyle nitelikli ve nadir olan kitapları toplamaya adamış bir "kitap muhibbanı" olduğu da anlaşılan Tevfik Bey, yabancı dil öğrenimine dair "öncü" kitaplarının dışında, edebi yönlerini ortaya çıkaran Pırlanta Mektuplar: Bir Sevdalının Muhaberat-ı Âşıkanesi adlı kısa bir roman da yazmıştır. Söz konusu romanın kapağında bulunan ve - muhtemelen - yayınlandığı dönemde Tevfik Bey'in okuyucuları açısından aşina olunsa da sonradan yazarının kim olduğunun anlaşılmasını güçleştiren S.M.T. imzası, tek başına bu kısa romanın Tevfik Bey'le ilişkilendirilmesi için yeterli değildir. Ancak romanın kurgusuna dâhil edilen mekânlar ve bazıları gerçek yaşamdan seçilmiş karakterlerin gerek Tevfik Bey gerekse de II. Meşrutiyet Döneminde İstanbul'da yaşayan İranlıların gerçek yaşamlarında karşılığa sahip olması, söz konusu romanın, nihayet diğer kitapları ve çeşitli makalelerinde S.M.T. imzası kullanmış olan Tevfik Bey'in kaleminden çıkmış olduğunu göstermektedir. Bu zeminde, Tevfik Bey'in yazdığı kitapların bulunması için yapılan araştırmalarda ulaşılan ve bulunduğu nadir eser kataloğunda yazarıyla ilişkilendirilemediği için fark

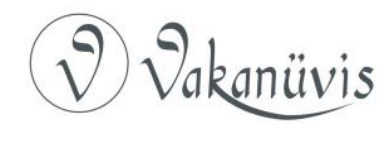


edilememiş S.M.T [س. م. ت.] imzalı romanın künye bilgileri aşağıdaki gibidir;

S.M.T., Pırlanta Mektuplar: Bir Sevdalının Muhaberat-ı Âşıkanesi, İstanbul: El-Adl Matbaası, 1925.

\section{Fihrist-i Kütübhâne-i Hususi}

Tevfik Bey'in Sebîlürreşâd dergisi dışındaki yazın hayatına dair araştırmalarda fark edilen ve üzerinde S.M. Tevfik imzası bulunan Fihrist-i Kütübhâne-i Hususi adlı kitap her ne kadar bir kütüphane fihristi olsa da içeriğindeki kitaplara dair şimdilerde ulaşılması pek mümkün olmayan önemli detaylar veriyor olduğu için, ayrıca bir kitap antolojisi olarak da değerlendirilebilir. Dolayısıyla bu antolojik fihrist, Tevfik Bey'in yazın kariyeri boyunca ürettiği eserlere dair bibliyografya listesine dâhil edilebilecekse de telif bir eser olmayıp, yazarın sahip olduğu zengin kütüphanesindeki kitapların künyelerini kaydetmek üzere hazırladığı bir liste olduğu için "S.M. Tevfik külliyatında" ayrı bir kategoride değerlendirilmelidir. Tevfik Bey, Türkçe, Farsça ve İngilizce dillerinde üç ayrı önsöz yazdığı bu kitapta, kütüphanesinde bulunan kitapların özelliklerinden bahsederken, gazetecilik kariyeri sırasında seyahat ettiği Hindistan coğrafyasıyla ilgili derinlikli bilgilerinden beslenen bazı önemli detaylar vermiştir. Bu bağlamda örneğin, kütüphanesinde bulunan ve Asiatic Society of Bengal [Bengal Cemiyet-i Asyaiyesi] tarafından yayınlamış bazı nadir kitapların menşeinden bahsettiği satırları söz konusu cemiyete dair bilgilendirici bir içerik taşımaktadır. Önsözünden başlayarak dönemin dolaşımda olan popüler kitapları kadar nadir bulunan çeşitli kitaplara dair de detaylar barındıran bu kitapta, ayrıca kitaplar konusunda hassasiyet sahibi olan bireyler için anlamlı olabilecek nasihatlerde bulunmuş olan Tevfik Bey, kitaplarını satanın manen çok şey kaybederken maddi olarak hiçbir şey kazanamayacağı uyarısında bulunmuş, "Saf temizi al, kederden uzak dur!" demiştir. Nihayet bir yönüyle aslında Tevfik Bey'in yazın hayatını da besleyen kitapların listelendiği bir kaynak olarak da değerlendirilebilecek olan ve sayfalarında sıralanan bazı nadir kitapların künye bilgilerine ulaşma olanağı sağlayan öğretici bir antoloji olan bu kitabın künye bilgileri aşağıdaki gibidir;

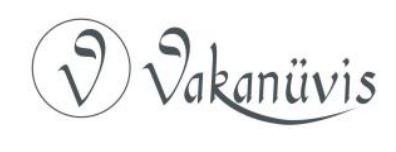


S.M. Tevfik, Fihrist-i Kütüphâne-i Hususi, İstanbul: Marifet Matbaası, 1927.

\section{Tevfik Okbatan Imzalı Tercüme}

Seyyid Muhammed Tevfik, Sebîlürreşâd kadrosuna dâhil olduktan sonra dergide kendi imzasıyla özgün makaleler yazan bir "muharrir" olarak çalışmasının yanı sıra, kökenleri ve uzmanlığı dolayısıyla hâkim olduğu Fars ve Hint coğrafyasında yayınlanan gazetelerde çıkan bazı makaleleri Sebîlürreşâd okurları için tercüme eden bir "mütercim" olarak da görev yapmıştır. Bu zeminde Tevfik Bey'in külliyatına dâhil edilebilecek olan ve mütercim kimliğiyle ilgili olarak ayrı bir kategoride değerlendirilmesi gereken bir başka kitap, Türk Tarih Kurumu tarafından yayınlanan Târîh-i Cihângüşâ olmuştur. Tevfik Bey'in "mütercim" olarak, S.M. Tevfik Okbatan adıyla yer aldığı ve İran tarih yazıcılı̆ındaki seçkin konumuyla İranlı Ata Melik Cüveynî tarafından Moğollar, Hârizmşahlar ve İsmâilîler'i anlatmak üzere yazılmış Târîhy-i Cihângüşâ hakkında bilgiler veren Özgüdenli'ye göre, bu kitabın 1938 yılında basılan ilk cildi hatalı bulunduğu için sonraki ciltleri yayınlanmamıştır. ${ }^{10}$ Dolayısıyla şaibeli bir hikâyesi de olduğu anlaşılan bu tercümedeki ilginç bir başka detay, diğer kitaplarında kendisini adeta "tanınamaz" kılan S.M.T. şeklindeki kısa imzayı tercih etmiş olan Tevfik Bey için, "Okbatan" şeklinde bir soyadı da kullanılmış olmasıdır. Bu soyadı, ilk bakışta nihayet bu üretken muharririn kimliğine dair önemli bir ipucu gibi duruyorsa da Târîh-i Cihângüşâ'nın geri çekilen ilk baskısının hikâyesi ve Tevfik Bey'in bu kitaptaki rolüyle ilgili belirsizliği arttırmaktadır. Zira gerek Nüfus İdaresi gerekse Erken Cumhuriyet Dönemi vefat kayıtlarına bakıldığında Türkiye çapında kullanımda olan yahut geçmişte kullanılmış herhangi bir "Okbatan" soyadına rastlanmamıştır. İlk baskısı muhtemelen üç cilt olarak planlanmışsa da sadece ilk cildi yayınlanmış ve bir şekilde yayından çekilmiş olan bu tercümenin künyesi aşağıdaki gibidir;

10 Osman Gazi Özgüdenli, "Târîh-i Cihângüşâ", TDV İslam Ansiklopedisi, 40, Ankara 2011, s.77.

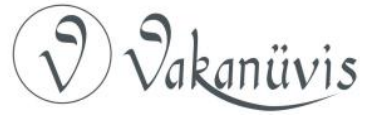


Ata Melik Alaüddîn-i Cüveyni, Tarihi Cihanküşa, C.1, Tercüme Eden: S.M. Tevfik Okbatan, Ankara: TTK, 1938.

\section{Meşrutiyet Döneminin Farklı Dillerdeki Süreli Yayınlarında Seyyid Muhammed Tevfik}

Babasının kökeni nedeniyle Farsça literatürde genellikle Seyyid Muhammed Tevfîk Hemedanî olarak anılan Tevfik Bey, yakın çağ İran tarihi açısından da önemli bir gazetecidir. Nitekim Tevfik Bey'in bu yönünün Sebîlürreşâd dergisinin kadrosunda yer almasının sebepleri arasında olduğunu söylemek de mümkündür. Sebîlürreşâd dergisinin 1912 yılında gerçekleşen yenilenme sürecinde yazı işleri kadrosuna "davet ettiği" Tevfik Bey, o sırada İstanbul'daki İran Okulu'nun yöneticiliğini yapmaktadır. Ancak Tevfik Bey'i İstanbul'daki İran diasporasına mensup şahsiyetler arasında öne çıkaran ve Sebîlürreşâd dergisine davet edilmesini sağlayan asıl meziyeti, dönemin İstanbul merkezli Farsça gazetelerindeki rolleriyle ilişkilidir. Zira Tevfik Bey, kariyerindeki bu gelişmeden birkaç yıl önce, İstanbul'da yaşayan meşrutiyet taraftarı İranlıların matbuat faaliyetlerinin bir parçası olarak yayınlanan Şems gazetesinin kadrosunda yer almıştır. İranlı bir yazar ve sonradan devlet adamı olan Seyyid Hasan Tebrizi'nin öncülüğünde çıkarılan Şems gazetesinin S.M. Tevfik'in gazetenin kadrosuna dâhil olmadan önceki bazı nüshaları, Tevfik Bey'in dönemin bazı meşrutiyet taraftarı İranlılarının düşünce dünyasındaki yerine dair önemli ipuçları da barındırmaktadır. Bu bağlamda Tevfik Bey'le ilgili, üretken olmasının yanı sıra o dönemde kalem ve kelamına itimat edilen bir muharrir olduğunun kanıtı olabilecek çeşitli ifadeler kullanmış olan Şems gazetesi, "ulu bilge" olarak takdim ettiği Tevfik Bey'i "emsalsiz bir edip" olarak tarif etmektedir. ${ }^{11}$ Tevfik Bey'in II. Meşrutiyet'in ilanından sonra editör olarak kadrosuna katıldığı Şems gazetesinin yayınları, başlangıçta İran'da entelektüel, modernist ve özgürlükçü düşüncenin yaygınlaşmasını hedefleyen yurtdışındaki İranlı sivil toplum örgütlerinin arasında öne çıkan Encümen-i Sa'âdet'in faaliyetleri ile uyumlu bir seyir izlemiştir. ${ }^{12}$

\footnotetext{
11 "Basralı Seyyid Muhammed Tevfik Bey", Şems, 24 Eylül 1908, s.7; Javad Bashari, Tevfik: Ruznamenegâr ve Majmooedar-e Iranî dar Istanbul, Tehran, s.22-23.

12 Rıza Kurtuluş, 1906-1911 İran Meşrutiyet Hareketinde Osmanlı Etkisi, Basılmamış Doktora Tezi, İstanbul 2010, s.185.
}

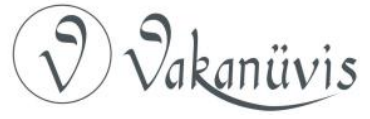


II. Meşrutiyet Döneminde İstanbul'da yayınlanan Farsça gazetelerden biri olan Şems'in bir süre sonra encümenle görüş ayrılığına düşmesi üzerine, Tevfik Bey'in bu defa müdür olarak görev yaptığı ve yine Farsça olarak çıkarılan Surûş gazetesi yayın hayatına başlamıştır. İran sınırları dışındaki muhalefetin önemli isimlerinin dahliyle yayınlanan Surûş gazetesi, bir nevi yurt dışındaki İran muhalefetinin resmi yayın organı gibi faaliyet göstermiştir. ${ }^{13}$

Temel kuruluş misyonu, İran'ın toprak bütünlüğünü koruyup, istikrar ve düzenini sağlamak olarak tarif edilen Encümen-i Saadet' in $^{14}$ bir üyesi olduğu da anlaşılan Tevfik Bey'in Şems ve Surûş gazetelerinden önce yayınlanan ve kendinden sonraki Farsça matbuatın ilham kaynağı da olan Ahter gazetesinde ${ }^{15}$ de yazmış olması muhtemeldir. Tevfik Bey'in Surûş gazetesinden sonra İstanbul'daki İran matbuatıyla ilgili bir sonraki girişimi Direfş adlı Farsça bir gazeteyle ilgili olmuştur. Tevfik Bey, ruhsat talebi Şerbetzâde Muhammed Ali tarafından yapılan ${ }^{16}$ ama bir şekilde hayata geçirilemediği anlaşılan bu gazeteyle ilgili girişimlerden birkaç yıl sonra bünyesine dâhil olduğu Sebîlürreşâd'daki kariyeri boyunca da İstanbul'daki Farsça matbuat hareketinden kopmamıştır. Bu bağlamda Tevfik Bey'in aynı zamanda Sebîlürreşâd'ın yazı heyetinde bulunduğu sıralarda dâhil olduğu bir başka Farsça gazete, 1914 yılının eylül ayında yayınlanmaya başlamış olan Hâver gazetesi olmuştur. Tevfik Bey'in yazı işleri müdürlügü yapmakta olduğu bu gazete, - onu, Şems gazetesini yayınlarken de gazetesinin yönetimine getirmiş olan - Seyyid Hasan Tebrizi'ye aittir. Aynı zamanda İstanbul'daki Farsça yayıncılığın önemli merkezlerinden biri olan Şems matbaasının sahibi de olan Seyyid Hasan Tebrizi'nin öncülüğünde kurulan ve ulaşılabilen nüshalarından anlaşıldığı kadarıyla Almanya lehine yayınlar yapmakta olan ${ }^{17}$ Hâver gazetesinin yayınları çeşitli dönemsel koşullar nedeniyle kesintiye uğramış ve 1927 yılından sonra dergi formatıyla çıkarılmıştır.

Tevfik Bey, 1908-1927 yılları arasında tarihlenen İstanbul merkezli Farsça gazetelerdeki kariyeri boyunca gerek muhabir gerek muharrir ve

\footnotetext{
${ }^{13}$ Browne, a.g.e., s.102; Kurtuluş, a.g.t., s.186.

${ }^{14}$ Kurtuluş, a.g.t., s.197.

${ }^{15}$ Rıza Kurtuluş, "Ahter", TDV İslam Ansiklopedisi, EK-1 Cilt, Ankara 2016, s.56-57.

${ }^{16}$ BOA, DH. MDK 180/11

17 Bashari, a.g.e., s.39-41.
}

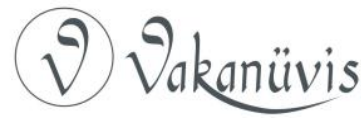


gerekse editör ve yazı işleri sorumlusu olarak yüzlerce Farsça makaleye imza atmıştır. Azmi Özcan'ın İngiliz arşiv belgelerine dayanarak naklettiği bilgilere göre Tevfik Bey, Hindistan merkezli Urduca bir gazete olan el-Hilâl'e ${ }^{18}$ de yazılar yazmıştır. ${ }^{19}$ Tevfik Bey'in, ilk sayısından itibaren İngiltere'nin İslâm ve Osmanlı politikasını şiddetle tenkit eden ve bu meseleler için özel bölümler ayıran el-Hilâl'deki yazılarını tespit etmek - şimdilik - mümkün olmamışsa da Sebîlürreşâd dergisindeki Hindistan Mektupları'ndan söz konusu gazetenin sahibi Ebü'l- Kelam Azad'la tekraren görüştüğü ve Özcan'ın ifadesiyle, "Urdu basınında bir dönüm noktası olan meşhur gazetesini", yakından takip ettiği anlaşılmaktadır. Benzer şekilde Tevfik Bey'in Pırlanta Mektuplar adlı eserini yayınlayan el-Adl matbaası sahibi Mehmed Safa Bey'in yönettiği el-Adl gazetesinin ${ }^{20}$ sık sık meşrutiyet taraftarı İran encümenlerince gönderilmiş yazılar yayınlamış olması, Tevfik Bey'in Arapça-Türkçe yayınlar yapan bu gazetede de yazılar yazmış olabileceğini düşündürmektedir.

\section{Meşrutiyet Dönemi Türkçe Basınında Tevfik Bey}

Tevfik Bey'in, II. Meşrutiyet Döneminde çoğunlukla "S.M.T." ve "S.M. Tevfik" imzalarıyla yayınladığı Farsça ve diğer yabancı dillerdeki yazılarına ait bibliyografyayı bu çalışmaya dâhil etmek, bir makalenin teknik ve şekilsel sınırlarını aşacağı için, çalışmanın sonraki bölümlerinde sadece, gazetecilik serüveni boyunca ürettiği Türkçe makaleler listelenecektir. Çoğunlukla kronolojik bir sıralamayla listelenecek olan makaleler, Miladi, Rumi ve Hicri takvimlerdeki tarihleriyle birlikte verilecek, bu sayede Tevfik Bey'in dönemin farklı dillerdeki çeşitli süreli yayınlarında farklı takvim kullanımlarıyla karşılaşılabilecek makalelerinin, buradaki listenin dışında kalanlarının daha kolay fark edilmesi sağlanacaktır. Bu zeminde Seyyid Muhammed Tevfik Hemedanî'nin Hindistan seyahati esnasında ve sonraki yıllarda, Osmanlı basın tarihinin satır aralarında kaybolan, Sebîlürreşâd dergisi dışındaki çeşitli Türkçe süreli yayınlarda, S.M.T. ve S.M. Tevfik imzalarını kullanarak yayınlandığı bazı makaleler bulmak mümkündür.

\footnotetext{
18 Azmi Özcan, "el-Hilâl", TDV İslam Ansiklopedisi, 18, Ankara 1998, s.20.

19 Azmi Özcan, Pan-İslamizm, Osmanlı Devleti, Hindistan Müslümanları ve Ingiltere [1877-1924], Ankara 1997, s.215.

${ }^{20}$ Ali Birinci, "Meşrutiyet Matbuatı (1324-1325) V", Kebikeç Dergisi, 6 (1998), s.88.
} 


\section{Şehbâl Dergisinde Tevfik Bey}

Tevfik Bey'in henüz Sebîlürreşâd kadrosuna dâhil olmasından önce Türkçe makalelerini yayınlamaya başladığı anlaşılan örnek süreli yayınlardan biri, edebi, fikri ve kültürel içeriğini zenginleştiren görselliğiyle de II. Meşrutiyet Döneminin özgün dergilerinden biri olan Şehbâl dergisi ${ }^{21}$ olmuştur. Tevfik Bey'in, söz konusu süreli yayında S.M.T. imzasıyla göze çarpan makalelerine ait künye bilgileri aşağıdaki gibidir;

S.M.T., "Atf-ı Nazar: Rusların İran'daki Mezalimine Ait Bir Tarihçe”, Şehbâl, 14 Temmuz 1911 [1 Temmuz 1327 - 17 Receb 1329], S.56, s.144-145.

S.M.T., "Menâzır-ı Milliyemizden: Bağdat'a Dâir Sezây-ı Dikkat Bazı Müşâhedeler", Şehbâl, 14 Şubat 1913 [1 Şubat 1328 - 7 Rebîülevvel 1331], S.69, s.408-411.

\section{Cerîde-î Sûfiyye Dergisinde Tevfik Bey}

Sebîlürreşâd'ı temsilen yaptığı Hindistan yolculuğundan döndükten sonra, dönemin tasavvuf ağırlıklı yayınları arasında en uzun ömürlüsü olan Cerîde-i Sûfiyye dergisinde ${ }^{22}$ de yazan Tevfik Bey'in, söz konusu süreli yayında S.M. Tevfik imzasıyla göze çarpan makalelerine ait künye bilgileri aşağıdaki gibidir;

S.M. Tevfik, "Sırp Sefiri ve Şark", Cerîde-i Sûfiyye, 6 Kasım 1915 [24 Teşrinievvel 1331 - 28 Zi'l-Hicce 1333], S.115, s.204.

\section{Seyyid Muhammed Tevfik'in Sebîlürreşâd Dergisi Makaleleri}

II. Meşrutiyet Dönemi İslamcılık hareketinin en önemli yayın organı olan ve başyazarlığını Mehmed Âkif'in yaptığı Sebîlürreşâd dergisi, yayın hayatına başladığı Ağustos 1908 tarihinden başlayarak geniş bir okuyucu kitlesine ulaşmış, nihayet Mart 1912'de yazar kadrosunun çeşitlendiği bir yeni yayın dönemine girmiştir. ${ }^{23}$ İstanbul'da çıkarılan Farsça gazetelerde oldukça aktif roller almış önemli bir gazeteci olduğu anlaşılan Seyyid Muhammed Tevfik Hemedanî'nin bu süreçte derginin kadrosuna katılması, üretken gazetecilik serüveninin önemli

\footnotetext{
${ }^{21}$ Nazım H. Polat, "Şehbâl", TDV İslam Ansiklopedisi, 38, Ankara 2010, s.423-424.

22 Mustafa Kara "Cerîde-i Sûfiyye", TDV İslam Ansiklopedisi, 7, Ankara 1993, s.410.

${ }^{23}$ Adem Efe, "Sebîlürreşâd", TDV İslam Ansiklopedisi, 36, Ankara 2009, s.251-253.
}

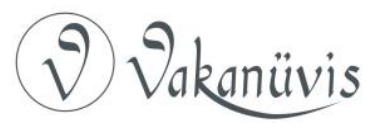


aşamalarından biri olmuştur. Nitekim bu gelişmenin, "âlem-i islâm hakkında vukūf-ı küllîleri olan bazı büyük Islâm muharrirlerine" yapılan "müracaatlar neticesinde" gerçekleştiğini duyuran Sebîlürreşâd dergisi, ${ }^{24}$ yeni yazar kadrosunun nasıl şekillendiğini anlattığı bu cümlelerin devamında, aralarında Tevfik Bey'in de bulunduğu yeni yazarlarının "isimleri bütün milletçe tanınmış olan zevât-ı muhteremeden" olduğunu ifade etmiştir. Dolayısıyla Sebîlürreşâd kadrosuna, II. Meşrutiyet Döneminde "milletçe tanınan büyük muharrirler"den biri olduğu için davet edildiği aşikâr olan Tevfik Bey'in bu dergideki yazılarının daha en başından derginin misyonuna katkı sağlayacağına dair beklentilerle yayınlandığı anlaşımaktadır. Sebîlürreşâd dergisindeki çeşitli yazılarında S.M.T. [. م. م. ت. Tevfik [س. م. ف وتىق] imzaları kullanan S.M. Tevfik'in, Sebîlürreşâd'daki ilk makalesi, derginin 28 Mart 1912 tarihli sayısında yayınlanmıştır. Mevcut kayıtlardan anlaşıldığı kadarıyla Mart 1912'den başlayarak, 1920 yılına kadar toplamda sekiz yıl boyunca Sebîlürreşâd'ın yazı işleri kadrosunda yer alan Tevfik Bey, yukarıda da bahsedildiği üzere, genellikle Sebîlürreşâd'a dâhil olduğu ilk yıllarda yazdığı Hindistan Mektupları ile anılıyorsa da Sebîlürreşâd sayfalarında yaklaşık yüz elli makale yayınlamıştır.

Tevfik Bey'in bazıları oldukça hacimli, içerik açısından detaylı olan ve II. Meşrutiyet Dönemi İslamcılık, Panislamizm ve Pantürkizm konulu çalışmalarda sık sık atıf yapılan Hindistan Mektupları ve bu mektupların öncesinde ve sonrasında yayınladığı makalelerin farklı araştırmalar için kaynaklık edebilecek şekilde, işlevsel olarak ayrıştırılıp sıralanması, bu çalışmanın sunuş metodolojisini oluşturmaktadır. Bu zeminde ilk olarak, Tevfik Bey'in Sebîlürreşâd kadrosuna dâhil olduktan sonraki ilk beş aylık süre zarfında dergide S.M.T. imzasıyla yayınlanan makalelerine ait künye bilgileri aşağıdaki gibidir;

S.M.T., "Osmanlı-iran Hudûdu ve Rusya”, Sebîlürreşâd, 28 Mart 1912 [15 Mart 1328 - 9 Rebîülâhir 1330], C.8, S.186, s.68-69.

S.M.T., "Edebiyât Yahud İran Târîh-i İnkılâbından Bir Yaprak", Sebîlürreşâd, 11 Nisan 1912 [29 Mart 1328 - 9 Rebiülâhir 1330], C.8, S.188, s.101-103.

24 "Sebîlürreşâd Cerîde-i İslâmiyyesi Heyet-i Tahrîriyyesi", Sebîlürreşâd, 8 Mart 1912, s.4.

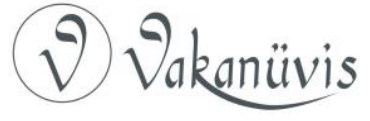


S.M.T., "Siyâsiyât: Fransa-Fas, Rusya-i̇an", Sebîlürreşâd, 11 Nisan 1912 [29 Mart 1328 - 9 Rebîülâhir 1330], C.8, S.188, s.106-108.

S.M.T., "Ruslar ve İranîler: Meşhed Bombardımanı", Sebîlürreşâd, 16 Mayıs 1912 [3 Mayıs 1328 - 29 Cemâziyelevvel 1330], C.8, S.193, s.203206.

S.M.T., "Zavallı Yefrem Han, İran Meşrutiyetinin Sonuncu Kurbanı", Sebîlürreşâd, 30 Mayıs 1912 [17 Mayıs 1328 - 13 Cemâziyelâhir 1330], C.8, S.195, s.244-247.

S.M.T., "Afganistan Hükümeti İslamiyesi", Sebîlürreşâd, 30 Mayıs 1912 [17 Mayıs 1328 - 13 Cemâziyelâhir 1330], C.8, S.195, s.247-248.

S.M.T., "Hilâl ve Salîb Yahud İslâm ve Nasrâniyet", Sebîlürreşâd, 13 Haziran 1912 [31 Mayıs 1328 - 27 Cemâziyelâhir 1330], C.8, S.197, s.284-285.

S.M.T., "Osmanlı-İran İttifâkı”, Sebîlürreşâd, 20 Haziran 1912 [7 Haziran 1328 - 5 Receb 1330], C.8, S.198, s.305-307.

S.M.T., "Hayât-ı Akvâm-ı İslâmiyye: Afganistan Müslümanları: Emîr Habîbullâh Hân'ın Ulviyeti ve Afganistan'da Âsâr-ı Tekâmül ve Terakkī”, Sebîlürreşâd, 27 Haziran 1912 [14 Haziran 1328 - 12 Receb 1330], C.8, S.199, s.327-329.

S.M.T., "Osmanlı - İtalya Muhârebesi ve Âlem-i İslâm'da Te'sîrâtı", Sebîlürreşâd, 4 Temmuz 1912 [21 Haziran 1328 - 19 Receb 1330], C.8, S.200, s.351-352.

\section{Tevfik Bey'in Hindistan Seyahati ve Hindistan Mektupları}

1912 yılının mart ayından itibaren Sebîlürreşâd bünyesinde yazılar yazmaya başlayan Tevfik Bey'in bu dergideki rolü, yukarıda da sık sık değinildiği üzere, özellikle Hindistan Mektupları başlığını taşıyan makaleleriyle görünür hale gelmiştir. Tevfik Bey'in Hindistan Mektuplarını yazmasını sağlayacak olan süreci, derginin muhtelif sayılarındaki duyuru ve haberlerden takip etmek mümkündür. Bu bağlamda derginin 4 Temmuz 1912 tarihli 200. sayısında bir haber verilmekte, "Islam dünyasının ilerlemesi için çalışmayı kendine vazife kılarak bu uğurda büyük fedakârlıklar yapmış olan" Sebîlürreşâd dergisinin, "Islâm Memleketlerine i'zâm" ettiği muhabirler arasında

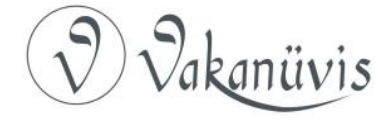


Tevfik Bey'in adı da verilmektedir. Hindistan, Türkistan, Türkmenistan, Buhara, Çin, Romanya ve Bulgaristan gibi memleketlere muhabir gönderme kararı alındığını duyuran dergi, tüm İslam dünyasını ilgilendiren bu yeni projesine "Şark ve garb lisânlarına vâkıf, ilm ü iktidârı, nâmûs u fa-zîleti bütün erbâb-ı matbûâtça müsellem" biri olarak tarif ettiği S.M. Tevfik'i de dâhil etmiştir. Tevfik Bey'in "Hindistan'a müteveccihen hareket ettiği" bilgisini veren aynı haberde, "memleketlerde yaşayan dindaşların ahvâl-i ictimâiyye ve terakkıyât-ı fikriyyelerinden haberdâr olmak, Müslümanlar arasındaki râbıta-i uhuvvet ve dîniyyeyi takviye etmek, hülâsa Müslümanları birbirine tanıttırmak"la görevlendirilen muhabirlerin, birkaç hafta sonra derginin Mekâtîb bölümünde yayımlanmak üzere mektup göndermeye başlayacakları bildirilmiştir. Bu haberin ardından Sebîlürreşâd sayfalarında "Hindistan Muhâbir-i Mahsûsamız" ifadesiyle takdim edilmeye başlanan S.M. Tevfik' in yeni görevi bağlamındaki ilk mektubu, söz konusu haberden yaklaşık bir ay sonra yayınlanmıştır.

Tevfik Bey, 1912 yılının temmuz ayı ortalarında "Sebîlürreşâd'ın Hindistan Muhâbiri" sıfatıyla çıktığı yolculuğunun sonunda 1913 yılı temmuz ayında Hindistan'a ulaşmıştır. Hindistan seyahati sırasında kaleme aldığı makaleler, Sebîlürreşâd'ın Mekâtîb sayfalarında, "Hindistan Mektupları" başlığıyla yayınlanmıştır. Yaklaşık iki yıl sonra, 1914 yılının haziran ayında İstanbul'a dönecek olan Tevfik Bey'in Hindistan Mektupları'nın Sebîlürreşâd'daki yayını, bu süreçte artık Osmanlı matbuatının da meşhur isimlerinden biri haline gelmiş olan bu üretken seyyahın İstanbul'a dönüşünden sonra tamamlanabilmiştir.

Tevfik Bey, İstanbul'dan başlayarak Güney Asya'ya uzanan oldukça geniş bir coğrafi hat üzerinde deniz ve kara yolculukları yaparak gerçekleştirdiği seyahati sırasında yaptığı gözlemler ve bağlantılı konulardaki görüşlerini, İslam dünyasının içinde bulunduğu koşullarla ilgili tespitleriyle harmanlayarak anlatmıştır. Tevfik Bey'in bu süreçteki gözlem ve tespitleri, I. Dünya Savaşı'nın hemen öncesinde Anadolu, Ortadoğu ve Güney Asya'daki sosyokültürel, siyasi ve ekonomik duruma projeksiyon tutan önemli detaylara sahiptir. Ancak Tevfik Bey'in imparatorluklar çağının kapanmakta olduğu bir zaman eşiğinde, kadim imparatorluklara ev sahipliği yapmış coğrafyalardaki bir devrin kapanışına tanıklık eden gözlemlerinin dönemle ilgili siyasi, kültürel ve

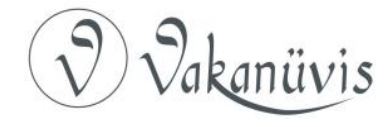


ekonomik araştırmalarda işlevsel olarak kullanılmasını sağlayacak içeriksel ve kronolojik bir tasnife ihtiyacı vardır. Bu nedenledir ki çalışmanın bundan sonraki bölümlerinde, Tevfik Bey'in Hindistan seyahati sırasında yazdığı ve Sebîlürreşâd sayfalarında Hindistan Mektupları üst başlığının altında yer alan makalelerin bazıları, ilgili literatürde bulunmayan ama içeriği özetlemek üzere kurgulanmış yeni alt başıklarla sıralanacaktır.

\section{Istanbul'dan Lübnan'a Seyahat Mektupları}

Tevfik Bey'in Hindistan yolculuğu sırasında ziyaret etme fırsatı bulduğu bazı farklı bölge, ülke ve kentlerle ilgili gözlemlerinin farklı alt başlıklar altında sıralanması, bu gözlemlerin yeni araştırmalara kaynaklık edecek şekilde fark edilebilmesi açısından daha işlevsel olacaktır. Bu bağlamda Tevfik Bey, Hindistan Mektupları'nın Sebîlürreşâd'ın Mekâtîb sayfalarında yayınlanan ilk bölümlerini oluşturuyorsalar da farklı bir başlık altında sıralanması gereken ilk makalelerini, İstanbul'dan denize açılarak Hindistan seyahatine başladığı gemi yolculuğu sırasında ve bu seyahatin Anadolu sınırları dışındaki ilk durağı olan Beyrut'ta yazmıştır. Tevfik Bey'in 1912 yılı temmuzunda İstanbul'dan ayrıldıktan sonra bir kısmını Ege ve Akdeniz'de uğradığı bazı liman kentlerinde bir kısmını da 1912 yılının ağustos ayında ulaştığı Lübnan' da yazdığı makalelerine ait künye bilgileri aşağıdaki gibidir;

S.M.T., "Hind Yolunda", Sebîlürreşâd, 1 Ağustos 1912 [19 Temmuz 1328 - 18 Şa'bân 1330], C.8, S.204, s.423-424.

S.M.T., "Hind Yolunda 2", Sebîlürreşâd, 8 Ağustos 1912 [26 Temmuz 1328- 25 Şa'bân 1330], C.8, S.205, s.446-448.

S.M.T., "Hind Yolunda 3", Sebîlürreşâd, 15 Ağustos 1912 [2 Ağustos 1328 - 02 Ramazan 1330], C.8, S.206, s.465-467.

S.M.T., "Hind Yolunda 4: Nüfûz-ı Ecânib, Beyrut Mektepleri", Sebîlürreşâd, 22 Ağustos 1912 [9 Ağustos 1328 - 9 Ramazan 1330], C.8, S.207, s.489-490.

S.M.T., "Hind Yolunda 5: Cebel-i Lübnan Ahvâli", Sebîlürreşâd, 29 Ağustos 1912 [16 Ağustos 1328 - 16 Ramazan 1330], C.8, S.208, s.505507.

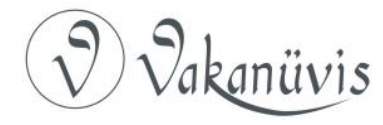


S.M. Tevfik, "Hind Yolunda 6: Beyrut Ahvâl-i Umûmiyyesi", Sebîlürreşâd, 5 Eylül 1912 [23 Ağustos 1328 - 23 Ramazan 1330], C.9, S.209, s.13-16.

\section{Suriye ve Irak Mektupları}

1912 yılının ağustos ayı sonunda yaptığı bir tren yolculuğu ile Haleb'e ulaşan Tevfik Bey, kısa bir süre burada konakladıktan sonra Irak'a geçmiştir. Seyahatinin bu aşamasında Bağdat, Kerbelâ, Necef ve Amâre gibi kentleri 1913 yılının temmuz ayına kadar dönüşümlü olarak dolaşacak olan Tevfik Bey'in Suriye ve Irak coğrafyasında bulunduğu yaklaşık bir yıllık süre zarfında yazdığı ve Sebîlürreşâd'ın Mekâtîb sayfalarında yayınlanan makalelerine ait künye bilgileri aşağıdaki gibidir;

S.M. Tevfik, "Hind Yolunda 7: Haleb Ahvâl-i Umûmiyyesi", Sebîlürreşâd, 12 Eylül 1912 [30 Ağustos 1328 - 30 Ramazan 1330], C.9, S.210, s.35-37.

S.M. Tevfik, "Hind Yolunda 8: Haleb-Bağdat Yolculuğu", Sebîlürreşâd, 26 Eylül 1912 [13 Eylül 1328 - 15 Şevval 1330], C.9, S.212, s.73-74.

S.M. Tevfik, "Hind Yolunda 9: Bağdat Hükûmetine Dair Ma'lûmât-ı Târîhhiyye", Sebîlürreşâd, 3 Ekim 1912 [20 Eylül 1328 - 22 Şevval 1330], C.9, S.213, s.94-95.

S.M. Tevfik, "Hind Yolunda 11: Bağdat Hükûmetine Dâir Ma'lûmât-ı Târîhhiyye", Sebîlürreşâd, 10 Ekim 1912 [27 Eylül 1328 - 29 Şevval 1330], C.9, S.214, s.112-113

S.M. Tevfik, "Hind Yolunda 13: Hıtta-i Irâkiyye Umâr-ı Zirâiyyesi Nasıl ìnyâ ve Islâh Olunur? 1", Sebîlürreşâd, 24 Ekim 1912 [11 Teşrînievvel 1328 - 11 Zilka' de 1330], C.9, S.216, s.154-155.

S.M. Tevfik, "Hind Yolunda 14: Hıtta-i Irâkiyye Umâr-ı Zirâiyyesi Nasıl inyâ ve Islâh Olunur? 2", Sebîlürreşâd, 31 Ekim 1912 [18 Teşrînievvel 1328 - 21 Zilka' de 1330], C.9, S.217, s.171-174.

S.M. Tevfik, "Hind Yolunda: Irâk'ın İhyâ ve Islâhı Hakkında 3", Sebîlürreşâd, 28 Kasım 1912 [15 Teşrînisânî 1328 - 19 Zilhicce 1330], C.9, S.220, s.222-223.

\section{(2) Vakanüvis}


S.M. Tevfik, "Hind Yolunda 15: Kerbelâ ve Necef Ulemâsı", Sebîlürreşâd, 12 Aralık 1912 [29 Teşrînisânî 1328 - 2 Muharrem 1331], C.9, S.222, s.255-257.

S.M. Tevfik, "Hind Yolunda 16: Kerbelâ ve Necef Ulemâsı 2", Sebîlürreşâd, 19 Aralık 1912 [6 Kânunîevvel 1328 - 9 Muharrem 1331], C.9, S.223, s.271-273

S.M. Tevfik, "Hind Yolunda 17: Bağdat Nakîbü'l-Eşrâfı Hazretleri", Sebîlürreşâd, 26 Aralık 1912 [13 Kânunîevvel 1328 - 16 Muharrem 1331], C.9, S.224, s.289-290.

S.M. Tevfik, "Hind Yolunda 18: Atebât'da Hissiyât-ı İslâmiyye", Sebîlürreşâd, 2 Ocak 1913 [20 Kânunîevvel 1328 - 23 Muharrem 1331], C.9, S.225, s.304-305.

S.M. Tevfik, "Hind Yolunda 19: Hindistan'da Hissiyât-ı İslâmiyye", Sebîlürreşâd, 9 Ocak 1913 [27 Kânunîevvel 1328 - 30 Muharrem 1331], C.9, S.226, s.320-322.

S.M. Tevfik, "Hind Yolunda 20: Müessir Bir Konferans", Sebîlürreşâd, 16 Ocak 1913 [3 Kânunîsânî 1328 - 8 Safer 1331], C.9, S.227, s.338-339.

S.M. Tevfik, "Hind Yolunda 21: Kerbelâ'da On Günlük Muharrem", Sebîlürreşâd, 6 Şubat 1913 [24 Kânunîsânî 1328 - 29 Safer 1331], C.9, S.230, s.384-386.

S.M. Tevfik, "Hind Yolunda 22: Harb-i Hâzırın Hindistan'daki Te'sîrâtı", Sebîlürreşâd, 13 Şubat 1913 [31 Kânunîsânî 1328 - 7 Rebîülevvel 1331], C.9, S.231, s.401-403.

S.M. Tevfik, "Hind Yolunda 23: Müdâfaa-i İslâmiyyet Hakkında Mühim Bir Eser", Sebîlürreşâd, 20 Şubat 1913 [7 Şubat 1328 - 14 Rebiülevvel 1331], C.9, S.232, s.418-419.

S.M. Tevfik, "Hind Yolunda 24: Irak'da Hissiyât", Sebîlürreşâd, 13 Mart 1913 [28 Şubat 1328 - 5 Rebîülâhir 1331], C.10, S.235, s.13.

S.M. Tevfik, "Hind Yolunda 25: Mühim Bir Mülakât", Sebîlürreşâd, 27 Mart 1913 [14 Mart 1329 - 19 Rebiülâhir 1331], C.10, S.237, s.51-52.

S.M. Tevfik, "Hind Yolunda 26", Sebîlürreşâd, 10 Nisan 1913 [28 Mart 1329 - 4 Cemâziyelevvel 1331], C.10, S.239, s.82-83.

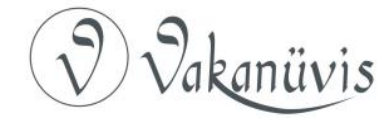


S.M. Tevfik, "Hind Yolunda 27: Irak-Âdem-i Merkeziyyet", Sebîlürreşâd, 17 Nisan 1913 [4 Nisan 1329 - 11 Cemâziyelevvel 1331], C.10, S.240, s.100-102.

S.M. Tevfik, "Hind Yolunda 28: Irak'ta Arablık-Türklük", Sebîlürreşâd, 24 Nisan 1913 [11 Nisan 1329 - 18 Cemâziyelevvel 1331], C.10, S.241, s.117-118.

S.M. "Tevfik, "Hind Yolunda 29: Kavmiyet-Nifâk ve Şikâk Tohumları", Sebîlürreşâd, 8 Mayıs 1913 [25 Nisan 1329 - 2 Cemâziyelâhire 1331], C.10, S.243, s.150-151.

S.M. Tevfik, "Hind Yolunda 30: İttihâd-ı Ulemâ-i A'lâm ve Cihâd Hakkındaki Fetvâları", Sebîlürreşâd, 15 Mayıs 1913 [2 Mayıs 1329 - 9 Cemâziyelâhire 1331], C.10, S.244, s.166-167.

S.M. Tevfik, "Hind Yolunda 31: Hind Müslümanları-Ingilizler", Sebîlürreşâd, 22 Mayıs 1913 [9 Mayıs 1329 - 16 Cemâziyelâhir 1331], C.10, S.245, s.185-187.

S.M. Tevfik, "Hind Yolunda 32: Bağdat Demiryolu", Sebîlürreşâd, 29 Mayıs 1913 [16 Mayıs 1329 - 23 Cemâziyelâhir 1331], C.10, S.246, s.202203.

S.M. Tevfik, "Hind Yolunda 33", Sebîlürreşâd, 5 Haziran 1913 [23 Mayıs 1329 - 30 Cemâziyelâhire 1331], C.10, S.247, s.218-219.

S.M. Tevfik, "Hind Yolunda 34: İran Jandarma Teşkilatı ve Ahvâl-i Inzibâtiyyesi", Sebîlürreşâd, 12 Haziran 1913 [30 Mayıs 1329 - 7 Receb 1331], C.10, S.248, s.232-233.

S.M. Tevfik, "Hind Yolunda 35: Mühim Bir Mülakât", Sebîlürreşâd, 19 Haziran 1913 [6 Haziran 1329 - 14 Receb-i Şerîf 1331], C.10, S.249, s.249-250.

S.M. Tevfik, "Hind Yolunda 36: Bağdad'dan Amâre'ye", Sebîlürreşâd, 26 Haziran 1913 [13 Haziran 1329 - 21 Receb-i Şerîf 1331], C.10, S.250, s.265-266.

S.M. Tevfik, "Hind Yolunda 37", Sebîlürreşâd, 3 Temmuz 1913 [20 Haziran 1329 - 28 Receb-i Şerîf 1331], C.10, S.251, s.281-282. 


\section{Şuûn Sayfalarında Tevfik Bey}

Tevfik Bey'in adı, Irak ve çevresindeki gözlemlerini okuyucularına aktardığı Temmuz 1912 - Temmuz 1913 tarihleri arasında kalan döneme ait Sebîlürreşâd nüshalarında Mekâtîb sayfalarının dışında kalan ve dünyanın çeşitli yerlerinde yaşanan gelişmeler ve olayların bölge uzmanlarının değerlendirmeleriyle aktarıldığı Şuûn sayfalarında da geçmektedir. Sebîlürreşâd'ın genellikle imzasız olarak yayınlanan Şuûn sayfalarında kendi uzmanlık alanına giren farklı imzasız yazılar da yazmış olduğu anlaşılan Tevfik Bey'in Irak coğrafyasında bulunduğu sırada, derginin Şuûn sayfalarında S.M. Tevfik imzasıyla yayınlanan yazılarına ait künye bilgileri aşağıdaki gibidir;

S.M. Tevfik, "Şuûn: Irak", Sebîlürreşâd, 27 Şubat 1913 [14 Şubat 1328 - 21 Rebîülevvel 1331], C.9, S.233, s.434.

S.M. Tevfik, "Şuûn: Maskat", Sebîlürreşâd, 27 Şubat 1913 [14 Şubat 1328 - 21 Rebiülevvel 1331], C.9, S.233, s.434.

S.M. Tevfik, "Şuûn: Hindistan", Sebîlürreşâd, 27 Şubat 1913 [14 Şubat 1328 - 21 Rebîülevvel 1331], C.9, S.233, s.436.

S.M. Tevfik, "Şuûn: Somal", Sebîlürreşâd, 27 Şubat 1913 [14 Şubat 1328 - 21 Rebîülevvel 1331], C.9, S.233, s. 436.

S.M. Tevfik, "Şuûn: Irak", Sebîlürreşâd, 24 Nisan 1913 [11 Nisan 1329 - 18 Cemâziyelevvel 1331], C.10, S.241, s.119.

S.M. Tevfik, "Şuûn: Basra ve Maskat", Sebîlürreşâd, 22 Mayıs 1913 [9 Mayıs 1329 - 16 Cemâziyelâhir 1331], C.10, S.245, s.188.

\section{Karaçi ve Bombay Mektupları}

İstanbul'dan ayrıldıktan yaklaşık bir yıl sonra Karaçi'ye ulaştığında daha evvelden kendisini ve babasını da tanıyan bir aile dostunun yanında konaklayan Tevfik Bey, yaklaşık iki hafta burada kaldıktan sonra "Küçük Londra" dediği Bombay'a geçmiştir. Tevfik Bey'in hem o sırada Osmanlı Devleti'nin karşı karşıya kaldığı siyasi ve askeri meselelere dair görüşlerini hem de Karaçi ve ardından yaklaşık iki ay kadar dolaştığı Bombay'daki gözlemlerini S.M. Tevfik imzasıyla aktardığı makalelerine ait künye bilgileri aşağıdaki gibidir;

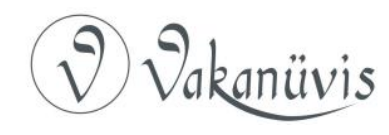


S.M. Tevfik, "Hindistan'a Muvâsalat", Sebîlürreşâd, 10 Temmuz 1913 [27 Haziran 1329 - 5 Şa'bânu'l-Muazzam 1331], C.10, S.252, s.295-297.

S.M. Tevfik, "Hindistan'ın İlk Sahili ve Hudûdu Karaçi Kasabası", Sebîlürreşâd, 17 Temmuz 1913 [4 Temmuz 1329 - 12 Şa'bânu'lMuazzam 133], C.10, S.253, s.314-316.

S.M. Tevfik, "Hindistan Mektupları: Bombay-Küçük Londra", Sebîlürreşâd, 24 Temmuz 1913 [11 Temmuz 1329 - 19 Şa'bânu'|Muazzam 1331], C.10, S.254, s.327-330.

S.M. Tevfik, "Hindistan Mektupları: Bombay Şehr-i Şehîri", Sebîlürreşâd, 31 Temmuz 1913 [18 Temmuz 1329 - 26 Şa'bânü'lMuazzam 1331], C.10, S.255, s.342-344.

S.M. Tevfik, "Hindistan Mektupları: Bombay Şehr-i Şehîri", Sebîlürreşâd, 7 Ağustos 1913 [25 Temmuz 1329 - 4 Ramazân-ı Şerîf 1331], C.10, S.256, s.357-360.

S.M. Tevfik, "Hindistan Mektupları: Bombay Şehr-i Şehîri", Sebîlürreşâd, 14 Ağustos 1913 [1 Ağustos 1329 - 11 Ramazân-ı Şerîf 1331], C.10, S.257, s.374-375.

S.M. Tevfik, "Hindistan Mektupları: Bombay Şehr-i Şehîri", Sebîlürreşâd, 21 Ağustos 1913 [8 Ağustos 1329 - 17 Ramazân-ı Şerîf 1331], C.10, S.258, s.392-395.

S.M. Tevfik, "Hindistan Hilâl-i Ahmer Hey'eti", Sebîlürreşâd, 28 Ağustos 1913 [15 Ağustos 1329- 25 Ramazân-ı Şerîf 1331], C.10, S.259, s.406-409.

S.M. Tevfik, “Muvaffakıyât-ı Osmâniyye'nin Hindistan'daki İn'ikâsâtı", Sebîlürreşâd, 4 Eylül 1913 [22 Ağustos 1329 - 2 Şevval 1331], C.10, S.260, s.418-421.

S.M. Tevfik, "Hindistan Mektupları: Edirne'nin Yeniden Fethi ve Hindistan Ahâlîi i İlâmiyyesinin Sevinçleri", Sebîlürreşâd, 11 Eylül 1913 [29 Ağustos 1329 - 9 Şevval 1331], C.11, S.261, s.7-8.

S.M. Tevfik, "Hissiyât-ı İslâmiyye: Tebrikler, Donanma, Cünbüşler, Nutuklar, Protestolar", Sebîlürreşâd, 18 Eylül 1913 [5 Eylül 1329 - 16 Şevval 1331], C.11, S.262, s.25-28.

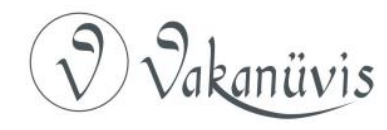


S.M. Tevfik, "Edirne-Hissiyât-ı İslâmiyye", Sebîlürreşâd, 25 Eylül 1913 [12 Eylül 1329 - 23 Şevval 1331], C.11, S.263, s.45-47.

S.M. Tevfik, "Hind Eşiği, Kapısı: Bombay", Sebîlürreşâd, 2 Ekim 1913 [19 Eylül 1329 - 1 Zilka'de 1331], C.11, S.264, s.57-60.

S.M. Tevfik, "Hind Demiryolları", Sebîlürreşâd, 9 Ekim 1913 [26 Eylül 1329 - 8 Zilka'de 1331], C.11, S.265, s.72-75.

\section{Madras Mektupları}

1913 yıııın Ekim ayı ortalarına kadar Bombay'da kalan Tevfik Bey, buradan sonra ülkenin güneydoğusunda bulunan ve mektuplarında "Hindistan'ın en kadîm ve en müzdahim şehirlerinden biridir. Hindistan'ın cihet-i cenûbîsinde vâki' olan şehr-i mezkûr, en meşhûr sevâhil-i ticâriyyeden ma'dûddur" ifadeleriyle tarif ettiği Madras'a geçmiştir. Büyük Hint coğrafyasındaki yüzlerce kilometrelik bir yolculuğun ardından ulaştığı Madras'taki gözlemlerini S.M. Tevfik imzasıyla anlattığı makalelerine ait künye bilgileri aşağıdaki gibidir;

S.M. Tevfik, "Madras Şehri", Sebîlürreşâd, 16 Ekim 1913 [3 Teşrînievvel 1329 - 15 Zilka'de 1331], C.11, S.266, s.90-93.

S.M. Tevfik, "Madras Şehri", Sebîlürreşâd, 23 Ekim 1913 [10 Teşrînievvel 1329 - 22 Zilka'de 1331], C.11, S.267, s.107-109.

S.M. Tevfik, "Madras Şehri", Sebîlürreşâd, 30 Ekim 1913 [17 Teşrînievvel 1329 - 29 Zilka'de 1331], C.11, S.268, s.122-124.

S.M. Tevfik, "Madras Şehri", Sebîlürreşâd, 6 Kasım 1913 [24 Teşrînievvel 1329 - 6 Zilhicce 1331], C.11, S.269, s.140-141.

\section{Seylan Mektupları}

Madras'tan sonra kendi ifadesiyle, "yirmi dört sâat şimendüferle, on iki sâat de vapurla" yolculuk ederek Seylan'a geçecek olan Tevfik Bey, Hindistan'ın güneyindeki küçük bir ada devleti olan ve günümüzde adı Sri Lanka olarak bilinen bu egzotik adadaki ziyareti sırasında, okuyucularına oldukça detaylı bilgiler veren makaleler yazmıştır. Adanın coğrafi özellikleri, ekonomisi ve tarihinin ve yanı sıra tıpkı diğer ziyaretlerindeki gibi burada Osmanlı Devleti'ni temsilen bulunan kişilerden de bahsetmiş olan Tevfik Bey'in seyahatinin bu aşamasında

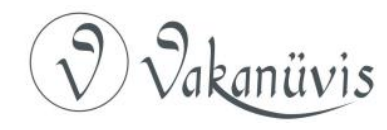


Sebîlürreşâd'ın Mekâtîb sayfaları için S.M. Tevfik imzasıyla kaleme aldığı makalelerine ait künye bilgileri aşağıdaki gibidir;

S.M. Tevfik, "Madras'tan Seylan Adasına", Sebîlürreşâd, 13 Kasım 1913 [31 Teşrînievvel 1329 - 13 Zilhicce 1331], C.11, S.270, s.153-155.

S.M. Tevfik, "Seylan Adası", Sebîlürreşâd, 20 Kasım 1913 [7 Teşrînisânî 1329 - 20 Zilhicce 1331], C.11, S.271, s.169-171.

S.M. Tevfik, "Seylan Adası Servet-i Tabîiyyesi", Sebîlürreşâd, 27 Kasım 1913 [14 Teşrînisânî 1329 - 27 Zilhicce 1331], C.11, S.272, s.186-188.

S.M. Tevfik, "Seylan Adası", Sebîlürreşâd, 4 Aralık 1913 [21 Teşrînisânî 1329 - 5 Muharrem 1332], C.11, S.273, s.203-205.

S.M. Tevfik, "Seylan Adası", Sebîlürreşâd, 11 Aralık 1913 [28 Teşrînisânî 1329 - 11 Muharrem 1332], C.11, S.274, s.217-219.

S.M. Tevfik, "Seylan Adası", Sebîlürreşâd, 18 Aralık 1913 [5 Kânunîevvel 1329 - 19 Muharrem 1332], C.11, S.275, s.233-235.

S.M. Tevfik, "Seylan Adası", Sebîlürreşâd, 25 Aralık 1913 [12 Kânunîevvel 1329 - 26 Muharrem 1332], C.11, S.276, s.250-253.

\section{Burma Mektupları}

Seylan Adasının merkezi olan Kolombo ve çevresindeki çeşitli temaslardan sonra bu defa Doğu'ya yönelerek beş günlük bir vapur yolculuğuyla Seylan'dan Güneydoğu Asya'daki Burma'ya geçen Tevfik Bey'in bu ülkenin merkezi olan Rangoon'dan başlayarak gerçekleştirdiği ziyaretleri sırasında Sebîlürreşâd'ın Mekâtîb sayfaları için S.M. Tevfik imzasıyla kaleme aldığı makalelerine ait künye bilgileri aşağıdaki gibidir;

S.M. Tevfik, "Seylan'dan Burma'ya", Sebîlürreşâd, 1 Ocak 1914 [19 Kânunîevvel 1329 - 4 Safer 1332], C.11, S.277, s.267-268.

S.M. Tevfik, "Burma Eyaleti”, Sebîlürreşâd, 8 Ocak 1914 [26 Kânunîevvel 1329 - 11 Safer 1332], C.11, S.278, s.279-280.

S.M. Tevfik, "Burma Eyaleti", Sebîlürreşâd, 15 Ocak 1914 [2 Kânunîsânî 1329 - 18 Safer 1332], C.11, S.279, s.299-300.

S.M. Tevfik, "Burma Eyaleti", Sebîlürreşâd, 22 Ocak 1914 [2 Kânunîsânî 1329 - 25 Safer 1332], C.11, S.280, s.316-318.

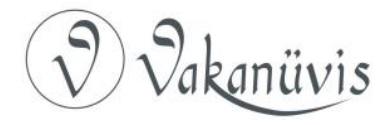


S.M. Tevfik, "Burma Eyaleti", Sebîlürreşâd, 29 Ocak 1914 [16 Kânunîsânî 1329 - 3 Rebiülevvel 1332], C.11, S.281, s.330-332.

S.M. Tevfik, "Burma Eyaleti", Sebîlürreşâd, 5 Şubat 1914 [23 Kânunîsânî 1329 - 9 Rebîulevvel 1332], C.11, S.282, s.349-350.

S.M. Tevfik, "Burma Eyaleti", Sebîlürreşâd, 12 Şubat 1914 [30 Kânunîsânî 1329 - 16 Rebîulevvel 1332], C.11, S.283, s.367-368.

S.M. Tevfik, "Burma Eyaleti", Sebîlürreşâd, 19 Şubat 1914 [6 Şubat 1329 - 23 Rebîulevvel 1332], C.11, S.284, s.383-384.

S.M. Tevfik, "Burma Eyaleti", Sebîlürreşâd, 26 Şubat 1914 [13 Şubat 1329 - 30 Rebîulevvel 1332], C.11, S.285, s.405-406.

S.M. Tevfik, "Şark-ı Karîb Gazetesi", Sebîlürreşâd, 5 Mart 1914 [20 Şubat 1329 - 7 Rebîulâhir 1332], C.11, S.286, s.422-423.

S.M. Tevfik, "Burma Eyaleti", Sebîlürreşâd, 12 Mart 1914 [27 Şubat 1329 - 14 Rebiülâhir 1332], C.12, S.287, s.13-15.

S.M. Tevfik, "Ingilizler Hindistan'da Nasıl Yerleştiler?", Sebîlürreşâd, 19 Mart 1914 [6 Mart 1330 - 21 Rebiülâhir 1332], C.12, S.288, s.33-36

\section{İstanbul'a Dönüş Arifesindeki Hindistan Mektupları}

Tevfik Bey'in 1914 yılında ocak ayında ulaştığı Burma'da aynı yılın mart ayı sonlarına kadar kaldığı anlaşılmaktadır. Burma'dan sonra yönünü tekrar Batı'ya doğru çevirecek olan Tevfik Bey, Burma'dan sonra Orta Hindistan'da bulunan Bhopal ve günümüzde Hindistan'ın en büyük ikinci kenti olan Delhi gibi şehirleri ziyaret etmiştir. Tevfik Bey'in artık Hindistan yolculuğunu tamamlamak üzere olduğu bu son aylarda, Sebîlürreşâd'ın Mekâtîb ve ayrıca bazı Matbûât sayfalarında çoğunlukla S.M. Tevfik imzasıyla yayınlanan makalelerine ait künye bilgileri aşağıdaki gibidir;

S.M. Tevfik, "Sâbık Hindistan Makarr-ı Hükümeti", Sebîlürreşâd, 26 Mart 1914 [13 Mart 1330 - 28 Rebiülâhir 1332], C.12, S.289, s.52-53.

S.M. Tevfik, "Sâbık Hindistan Makarr-ı Hükümeti", Sebîlürreşâd, 2 Nisan 1914 [20 Mart 1330 - 6 Cumâdelevvel 1332], C.12, S.290, s.71-72. 
S.M. Tevfik, "Sâbık Hindistan Makarr-ı Hükümeti", Sebîlürreşâd, 9 Nisan 1914 [27 Mart 1330 - 13 Cumâdelevvel 1332], C.12, S.291, s.8991.

S.M. Tevfik, "Hind Müslümanlarının ìki Büyük Cem'iyeti", Sebîlürreşâd, 16 Nisan 1914 [3 Nisan 1330 - 20 Cumâdelevvel 1332], C.12, S.292, s.105-107.

S.M. Tevfik, "Matbûât: Hindistan Matbûât-ı İslâmiyyesi Ne Hâldedir?", Sebîlürreşâd, 16 Nisan 1914 [3 Nisan 1330 - 20 Cumâdelevvel 1332], C.12, S.292, s.108-110.

S.M. Tevfik, "Hindistan Müslümanlarının İlmi ve Siyasi Cem'iyetleri", Sebîlürreşâd, 30 Nisan 1914 [17 Nisan 1330 - 4 Cumâdelevvel 1332], C.12, S.294, s.140-142.

[ísimsiz], "Matbûât: Hindistan Müslümanları ve Besledikleri Emeller", Sebîlürreşâd, 30 Nisan 1914 [17 Nisan 1330 - 4 Cumâdelevvel 1332], C.12, S.294, s.147.

S.M. Tevfik, "Hakīkī, Târîhî Hindistan", Sebîlürreşâd, 7 Mayıs 1914 [24 Nisan 1330 - 11 Cumâdelâhir 1332], C.12, S.295, s.163-164.

S.M. Tevfik, "Ekber Şah", Sebîlürreşâd, 14 Mayıs 1914 [1 Mayıs 1330 - 18 Cumâdelâhir 1332], C.12, S.296, s.182-184.

S.M. Tevfik, "Hindistan'da Tıbb-ı Kadîm-i Yunanî", Sebîlürreşâd, 21 Mayıs 1914 [8 Mayıs 1330 - 25 Cumâdelâhir 1332], C.12, S.297, s.204205.

S.M. Tevfik, "Hindistan'da İslam Moğolların Âsârı", Sebîlürreşâd, 28 Mayıs 1914 [15 Mayıs 1330 - 3 Recep1332], C.12, S.298, s.224-225.

S.M. Tevfik, "Hindistan Mektupları: Moğol İmparatorlarının Âsar-ı Ber-Güzîdeleri", Sebîlünnecât, 18 Haziran 1914 [5 Haziran 1330 - 24 Receb 1332], C.12, S.301/2, s.270-272.

S.M. Tevfik, "Hindistan Mektupları: Moğol İmparatorlarının Âsar-ı Ber-Güzîdeleri: Delhi'deki Müze Muhteviyatı", Sebîlürreşâd, 25 Haziran 1914 [12 Haziran 1330 - 1 Şa'bân 1332], C.12, S.302, s.288-290. 


\section{Seyyid Muhammed Tevfik'in Hindistan Seyahati Sonrasındaki Sebîlürreşâd Makaleleri}

Seyyid Muhammed Tevfik Hemedanî'nin Sebîlürreşâd dergisinin 1 Ağustos 1912 tarihli 204. sayısından başlayarak 25 Haziran 1914 tarihli 302. sayısına kadar, pek fazla kesintiye uğramadan yayınlanan Hindistan Mektupları, Hindistan'dan ayrılmadan hemen önce, bir zamanların şanlı imparatorluklarına ev sahipliği yapmış olan Hindistan ve dünya Müslümanlarının "uyudukları uykudan ne zaman uyanacakları" sorusuyla bitmektedir. Bu ibretli soruyu dile getirirken, Delhi'deki bir eski zaman sarayında bulunan "yıkık duvarlar içerisinde gayri ihtiyarı gözyaşı" döktüğünü de ifade etmiş olan Tevfik Bey, "Sebîlürreşâd'ın Hindistan Muhâbiri" sıfatıyla çıktığı Hindistan seyahatini tamamlayarak İstanbul'a döndükten sonra da bazıları derginin Makālât adını taşıyan sayfalarında yayınlanan çok sayıda makale kaleme almıştır. Bu süre zarfında derginin yazı işlerindeki idari görevini sürdürdüğü de anlaşılan Tevfik Bey'in Sebîlürreşâd makalelerinin kronolojisinde Kasım 1915 ile Ağustos 1918 tarihleri arasında kalan dönemde aylar süren kesintiler göze çarpmaktadır. Ancak derginin yayın politikaları nedeniyle II. Meşrutiyet Dönemi hükümetinden tepki görerek 1916 sonbaharında kapatılıp 1918 yılı ortalarına kadar kapalı kaldığı düşünüldüğünde, yazılarının tarih aralığındaki boşluğun bir kısmının aslında Sebîlürreşâd'ın kapalı olduğu döneme karşılık geldiği söylenebilir. Bu zeminde Tevfik Bey'in Hindistan seyahatini tamamlayarak İstanbul'a döndüğü 1914 yılının haziran ayından başlayarak 1920 yılına kadar Sebîlürreşâd dergisinde çoğunlukla S.M. Tevfik imzasıyla yayınlandığı tespit edilebilen son dönem makalelerine ait künye bilgileri aşağıdaki gibidir;

S.M. Tevfik, "Kur'ân ve İncil", Sebîlürreşâd, 9 Temmuz 1914 [26 Haziran 1330 - 15 Şa'bân 1332], C.12, S.304, s.323-324.

S.M. Tevfik, "Terbiye ve Ta'lîm: Bhopal Hâkime-i Zî-Şânı Şah Cihan Hazretlerinin Hindistan'da Esâsât-ı İslâmiyye Dâiresinde Kız Mektepleri Küşâdı", Sebîlürreşâd, 30 Temmuz 1914 [17 Temmuz 1330 - 7 Ramazan 1332], C.12, S.307, s.364-365.

S.M. Tevfik, "Harb-i Umûmî ve Âlem-i İslâm: İngilizleri Pek Geç Tanıdık", Sebîlürreşâd, 2 Eylül 1914 [20 Ağustos 1330 - 11 Şevval 1332], C.12, S.309, s.393-395.

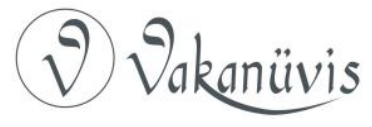


S.M. Tevfik, "Âlem-i İslâm: Bütün Müslümanlar I'tilâf-ı Müselles Aleyhinde Ayaklandılar", Sebîlürreşâd, 3 Aralık 1914 [20 Teşrînisânî 1330 - 14 Muharrem 1333], C.13, S.316, s.29-30.

S.M. Tevfik, "islâm Düşmanları Ne Yüzle Müslümanlardan Sadâkat Bekliyorlar?", Sebîlürreşâd, 17 Aralık 1914 [4 Kânûnievvel 1330 - 29 Muharrem 1333], C.13, S.318, s.43-45.

S.M. Tevfik, "Makālât: İslâm'ın Zafer Günüdür, Sevinmeli", Sebîlürreşâd, 31 Aralık 1914 [18 Kânûnievvel 1330 - 13 Safer 1333], C.13, S.320, s.61-63.

S.M. Tevfik, "Makālât: İslâm'ın Zafer Günüdür, Sevinmeli", Sebîlürreşâd, 7 Ocak 1915 [25 Kânûnievvel 1330 - 20 Safer 1333], C.13, S.321, s.69-71.

S.M. Tevfik, "Makālât: İran'da Cihâdın Te'sîrâtı", Sebîlürreşâd, 21 Ocak 1915 [8 Kânûnisânî 1330 - 5 Rebîülevvel 1333], C.13, S.323, s.8384.

S.M. Tevfik, "Makālât: Bütün Âlem-i İslâm Hâl-i İntibâh ve Kıyâmdadır", Sebîlürreşâd, 11 Şubat 1915 [29 Kânûnisânî 1330 - 26 Rebîülevvel 1333], C.13, S.326, s.109-110.

S.M. Tevfik, "Ahvâl-i Umûmiyyeye Bir Nazar", Sebîlürreşâd, 25 Şubat 1915 [12 Şubat 1330 - 10 Rebiülâhir 1333], C.13, S.328, s.125-126.

S.M. Tevfik, "Çanakkale Bombardımanı ve Te'sîrâtı", Sebîlürreşâd, 4 Mart 1915 [19 Şubat 1330 - 17 Rebîülâhir 1333], C.13, S.329, s.133.

S.M. Tevfik, "Âlem-i İslâm ve I'tilâf-ı Müselles", Sebîlürreşâd, 25 Mart 1915 [12 Mart 1331 - 9 Cemâziyelevvel 1333], C.13, S.332, s.156-158.

S.M. Tevfik, "Şark İşe Karışıyor", Sebîlürreşâd, 8 Nisan 1915 [26 Mart 1331 - 23 Cemâziyelevvel 1333], C.13, S.334, s.172-173.

S.M. Tevfik, "Sulh Gürültüleri", Sebîlürreşâd, 15 Nisan 1915 [2 Nisan 1331 - 30 Cemâziyelevvel 1333], C.13, S.335, s.182.

S.M. Tevfik, "Makālât: Harbin Onuncu Ayı: Zafer Bizde", Sebîlürreşâd, 20 Mayıs 1915 [7 Mayıs 1331 - 6 Receb 1333], C.14, S.339, s.6-7.

S.M. Tevfik, "Harb-i Umûmî̀nin Senesi", Sebîlürreşâd, 24 Haziran 1915 [11 Haziran 1331 - 11 Şa'bân 1333], C.14, S.343, s.39-40.

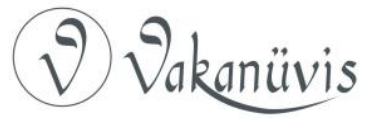


S.M. Tevfik, "Makālât: Fevz ü Zafer Bizimdir", Sebîlürreşâd, 26 Temmuz 1915 [13 Temmuz 1331- 13 Ramazan 1333], C.14, S.345, s.5556.

S.M. Tevfik, "Makālât: İntibâh-ı İslâm", Sebîlürreşâd, 16 Eylül 1915 [3 Eylül 1331- 7 Zilka'de 1333], C.14, S.348, s.79-80

S.M. Tevfik, "Makālât: Sırp Seferi ve Şark", Sebîlürreşâd, 28 Ekim 1915 [15 Teşrînievvel 1331 - 19 Zilhicce 1333], C.14, S.350, s.95-96.

S.M. Tevfik, "Makālât: İstanbul-Berlin Muvâsalesi: Harb-i Umûmî'yi Şark Seferi Netîcelendirecektir", Sebîlürreşâd, 11 Kasım 1915 [29 Teşrînievvel 1331 - 3 Muharrem 1334], C.14, S.351, s.103-104.

S.M. Tevfik, "İran'ın Fedâkârlığı”, Sebîlürreşâd, 22 Ağustos 1918 [22 Ağustos 1334 - 15 Zilka'de 1336], C.15, S.366, s.31-32.

S.M. Tevfik, "Osmanlı İttifâkının Kıymeti", Sebîlürreşâd, 29 Ağustos 1918 [29 Ağustos 1334 - 22 Zilka'de 1336], C.15, S.367, s.54-56.

S.M. Tevfik, "İttihâd-ı İslâm Tarafdârânı", Sebîlürreşâd, 5 Eylül 1918 [5 Eylül 1334 - 29 Zilka'de 1336], C.15, S.368, s.69-71.

S.M. Tevfik, "İslâm Siyâsetine Muhtâcız", Sebîlürreşâd, 31 Ekim 1918 [31 Teşrînievvel 1334 - 24 Muharrem 1337], C.15, S.376, s.228-231.

S.M. Tevfik, "Osmanlı - I'tilâf Münâsebât-ı Müstakbelesi", Sebîlürreşâd, 7 Kasım 1918 [7 Teşrînisânî 1334 - 1 Safer 1337], C.15, S.377, s.250-251.

S.M. Tevfik, "Ingilizlerin Sırr-ı Muvaffakiyeti ve Almanlar Niçin Mağlûb Oldular", Sebîlürreşâd, 15 Kasım 1918 [15 Teşrînisânî 1334 - 8 Safer 1337], C.15, S.378, s.263-266.

S.M. Tevfik, "islâmiyet ve Nasrâniyet: Ermenilerin ve Rumların Gürültüleri, İrtikâb Ettikleri Cinayetler", Sebîlürreşâd, 19 Aralık 1918 [19 Kânûnievvel 1334 - 15 Rebîülevvel 1337], C.15, S.383, s.3345-348.

S.M. Tevfik, "Memleketi Kurtaracak Ancak İslâmî Bir Teşkîlâttır, íbtidâları Müslümanların Muhabbetini Kazanan İttihâd ve Terakkî Bilâhare Müslümanların Nazarında Neden Düştü?", Sebîlürreşâd, 30 Ocak 1919 [30 Kânûnisânî 1335 - 27 Rebîülâhir 1337], C.15, S.389, s.439-441.

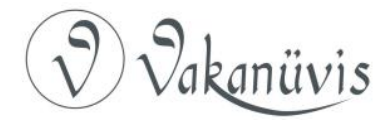


S.M. Tevfik, "Saltanat-ı İslâmiyye İttihâd ve Adâletle Dünyâya Hâkim Oldu Nifâk ve Sefâhetle Bugünkü Hâle Geldi!", Sebîlürreşâd, 5 Şubat 1919 [5 Şubat 1335 - 4 Cemâziyelevvel 1337], C.15, S.390, s.451-453.

S.M. Tevfik, "Avrupa'da ve Bizde Fırkacılık", Sebîlürreşâd, 5 Şubat 1919 [5 Şubat 1335 - 4 Cemâziyelevvel 1337], C.15, S.390, s.456-458.

S.M.T., "Vahdetten Ayrılan Milletlerin Âkıbeti İzmihlâldir", Sebîlürreşâd, 13 Şubat 1919 [13 Şubat 1335 - 12 Cemâziyelevvel 1337], C.16, S.391, s.11-12.

S.M.T., "Wilson Prensipleri Revâc Bulabilecekler mi?", Sebîlürreşâd, 13 Şubat 1919 [13 Şubat 1335 - 12 Cemâziyelevvel 1337], C.16, S.391, s.14-16.

[ísimsiz], "islâm Memleketlerine Göz Dikenlerin ìtirâsları?", Sebîlürreşâd, 6 Mart 1919 [6 Mart 1335 - 4 Cemâziyelâhir 1337], C.16, S.394-5, s.62-63.

S.M.T., "Arabistan İmparatorluğu", Sebîlürreşâd, 13 Mart 1919 [13 Mart 1335 - 10 Cemâziyelâhir 1337], C.16, S.396-7, s.76-78.

[ísimsiz], "Asya-yı Merkezî'de İslâm Hükûmât-ı Müttehidesi", Sebîlürreşâd, 13 Mart 1919 [13 Mart 1335 - 10 Cemâziyelâhir 1337], C.16, S.396-7, s.78-79.

[isimsiz], "Rusya'da Hareket-i İslâmiyye", Sebîlürreşâd, 13 Mart 1919 [13 Mart 1335 - 10 Cemâziyelâhir 1337], C.16, S.396-7, s.79-80.

S.M.T., "Sulh Konferansı ve Asya Hükûmetleri", Sebîlürreşâd, 20 Mart 1919 [20 Mart 1335 - 17 Cemâziyelâhir 1337], C.16, S.398-9, s.94-96.

S.M.T., "Asya Akvâmı ve Sulh Konferansı", Sebîlürreşâd, 27 Mart 1919 [27 Mart 1335 - 24 Cemâziyelâhir 1337], C.16, S.401-1, s.109-112.

S.M.T., "Sulh Mes'elesinde Mevkiimiz", Sebîlürreşâd, 3 Nisan 1919 [3 Nisan 1335 - 2 Receb 1337], C.16, S.402-3, s.126-128.

S.M. Tevfik, "Hindistan Muhtariyeti", Sebîlürreşâd, 15 Ocak 1920 [15 Kânûnisânî 1335 - 23 Rebiülâhir 1338], C.18, S.455, s.156. 


\section{Sonuç}

Seyyid Muhammed Tevfik Hemedanî'nin, mevcut kayıtlardan hareketle toplamda sekiz yıl sürdüğü anlaşılan Sebîlürreşâd kariyeri boyunca yazdığı makaleler arasında ulaşılabilen son yazısı, aynı zamanda birkaç satırı dönemin sansürü tarafından çıkarılmış olan "Sulh Meselesinde Mevkiimiz" başlığını taşımaktadır. Sebîlürreşâd'daki bu son yazısını "Biz Müslümanlar hak-şinas, sadık, cesur ve ahde vefakâr insanlarız" diyerek bitirecek olan Tevfik Bey'in, Sebîlürreşâd'daki kariyerinin nasıl sona erdiği ve sonraki dönemde derginin kurumsal yapısı ve bu yapının parçası olan idari kadro ve yazarlarla nasıl bir ilişki içerisinde olduğu araştırılması gereken bir başka önemli husustur. Nihayet I. Meşrutiyet Dönemindeki gazetecilik kariyerinin Hindistan Mektupları'ndan ibaret olmadığı, ayrıca İngilizce özelinde yabancı dil öğrenimiyle ilgili olarak, yayınlandıkları dönem ve kullandıkları kaligrafi bağlamında eğitim tarihi açısından da önemli olan kitaplar da hazırlamış bir muharrir olduğu anlaşılan S.M. Tevfik'in, Türkçedeki ulaşılabilen yayınlarının tanıtıldığı bu makaleyle gerçekten üretken bir gazeteci ve muharrir olduğu ortaya konulmuştur. Literatürde adı bazen [Çerkeşîzâde] Mehmed Tevfík, Sofîzâde Mehmet Tevfik [Safoğlu], Süleyman Tevfik [Özzoroğlu] ve Mehmet Tevfik [Biren] gibi, bir kısmı jenerasyon olarak da farklı kuşaklardan kişilerle karıştırılan Seyyid Muhammed Tevfik Hemedanî'nin dönemin süreli yayınlarında kendine has bir imzayla yayınladığı makalelerinin ve kitaplarının asıl kimliğiyle ilişkilendirilmesiyle, 20. yüzyılın ilk çeyreğinde imza attığı külliyatın gerçek boyutları ortaya konulmaya çalışılmıştır. Bu zeminde, sonraki çalışmalarda Tevfik Bey'in gerek Sebîlürreşâd ve gerekse eş zamanlı olarak yazılar yazdığı II. Meşrutiyet Dönemi matbuatının diğer aktörleriyle ilişkilerinin aydınlatılmasının aynı zamanda bir devrin matbuat evreninin anlaşılmasına katkı sağlayacağı düşünülmektedir. Külliyatını oluşturan farklı içeriklerdeki eserlerini, S.M.T. [.]. م. ت] ve S.M. Tevfik imzaları ile neşreden Seyyid Muhammed Tevfik Hemedanî'nin geride aslında adının baş harflerinden oluşan "üç harflik" bir imzaya sığmayacak aksiyoner bir yaşam hikâyesi ve oldukça zengin bir yazın bıraktığı aşikârdır. İran Meşrutiyet hareketi ve Osmanlı Devleti'ndeki İslamcı neşriyatta kendine has önemli bir yeri olduğu anlaşılan Tevfik Bey'in biyografisinin tüm yönleriyle ortaya çıkarılması, Osmanlı Devleti'nin son asrında ortaya çıkan "payitaht merkezli" siyasi

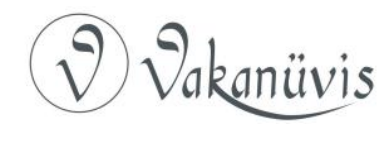


düşünce akımlarının İran, Irak, Afganistan ve Hindistan güzergâhındaki sözcüleri ve bu sözcülerin kendi aralarında kurdukları ilişkilerdeki kayıp halkaların tamamlanabilmesi için de hayati önem arz etmektedir. Bizzat kendi ömrünü çoklu coğrafyalar ve diller üzerinden politik bir önerme olarak geçirdiği anlaşılan Tevfik Bey'in, Seyyid Muhammed Tevfik Hemedanî olarak kurduğu ilişkiler ve bu makalede künyeleriyle bir araya getirilen külliyatı, Sasanî’nin “güzelliği ile Zengî, çalışkanlığı ile Türk, huyu ile Rum ve sözü ile Hint" olarak tarif ettiği Seyyid Muhammed Tevfik Hemedanî'nin İslamcı neşriyat literatürüne oldukça büyük bir katkı sağladığına işaret etmektedir.

\section{Kaynakça}

"Basralı Seyyid Muhammed Tevfik Bey", Şems, 24 Eylül 1908, s.7-8.

"Ingilizce Elifbâ ve Usûl-i Tedris", Sebîlürreşâd, 17 Nisan 1919, s.160.

"Sebîlürreşâd Cerîde-i İslâmiyyesi Heyet-i Tahrîriyyesi", Sebîlürreşâd, 8 Mart 1912. s.4.

"Sebîlürreşâd'ın Yeni ve Mühim Bir Teşebbüsü: İslâm Memleketlerine Muhbirler i'zâmı", Sebîlürreşâd, 4 Temmuz 1912, s.334-335.

"Saiyid Muhammad Tewfik, Chamberlain to Muhammed Ali Mirza", Who's Who in Persia, II, Sımla 1923, p.339.

S.M. Tevfik, "Madras Şehri", Sebîlürreşâd, 16 Ekim 1913, s.90-93.

S.M. Tevfik, "Seylan Adası", Sebîlürreşâd, 20 Kasım 1913, s.169-171.

Bashari, Javad, Tevfik: Ruznamenegâr ve Majmooedar-e Iranî dar Istanbul, Tehran 2017.

Birinci, Ali, "Meşrutiyet Matbuatı (1324-1325) V", Kebikeç Dergisi, 6 (1998), s.87-89.

Browne, Edward Granville, Press And Poetry of Modern Persia, Cambridge 1914.

Efe, Adem, "Sebîlürreşâd", TDV İslam Ansiklopedisi, 36, Ankara 2009, s.251253.

Han Melik Sasanî, Payitahtın Son Yıllarında Bir Sefir, çev. Hakkı Uygur, istanbul 2006.

Kara, Mustafa, "Cerîde-i Sûfiyye", TDV İslam Ansiklopedisi, 7, Ankara 1993, s.410.

Kurtuluş, Rıza, "Ahter", TDV islam Ansiklopedisi, EK-1 Cilt, Ankara 2016, s.56-57.

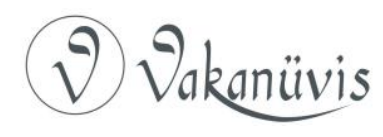


Kurtuluş, Rıza, 1906-1911 İran Meşrutiyet Hareketinde Osmanlı Etkisi, Basılmamış Doktora Tezi, İstanbul 2010.

Özcan, Azmi, Pan-İslamizm, Osmanlı Devleti, Hindistan Müslümanları ve ingiltere [1877-1924], Ankara 1997.

Özcan, Azmi, "el-Hilâl", TDV İslam Ansiklopedisi, 18, Ankara 1998, s.20.

Özgüdenli, Osman Gazi, "Târîh-i Cihângüşâ", TDV İslam Ansiklopedisi, 40, Ankara 2011, s.77-79.

Polat, Nazım H., "Şehbâl”, TDV İslam Ansiklopedisi, 38, Ankara 2010, s.423424.

Sharp. Dorothy Candlish, Early Childhood Programs: A Study of Provision for Kindergartem and Pre-School Programs in Newfoundland, Unpublished Masters Thesis, Newfoundland 1976.

TC Cumhurbaşkanlığı Osmanlı Arşivi (BOA). Dahiliye Nezareti Matbuat-ı Dahiliye Kalemi (DH. MDK). 180/11, 2 Zi'l-Hicce 1328 [5 Aralık 1910]

TC Cumhurbaşkanlığı Osmanlı Arşivi (BOA). Zaptiye Nezareti Belgeleri (ZB). 104/36-0 24 Ağustos 1324 [6 Eylül 1908]

Wasti, Syed Tanvir, "The Indian Red Crescent Mission to the Balkan Wars", Middle Eastern Studies, 45:3 (2009), p.393-406. 


\section{EKLER}
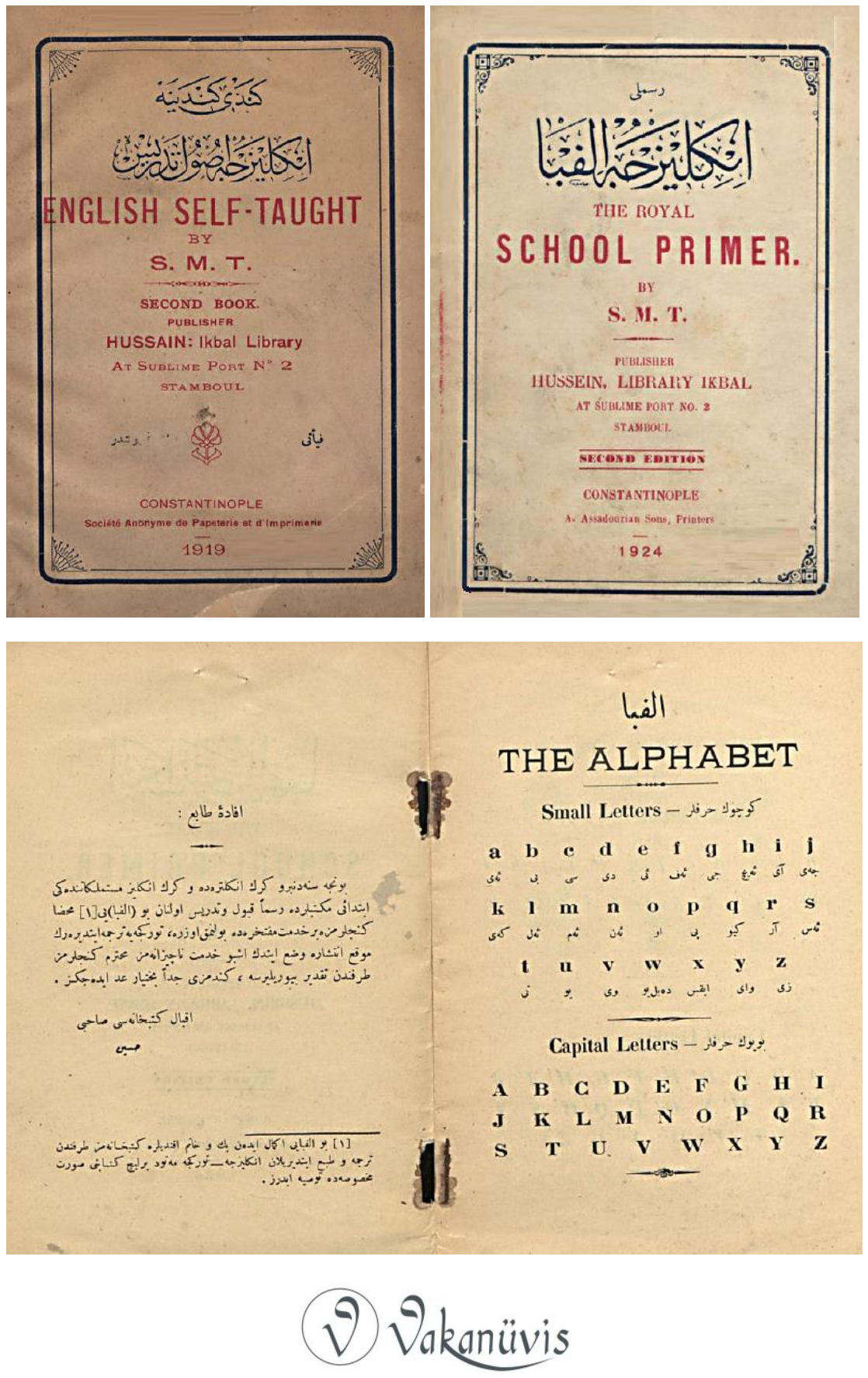

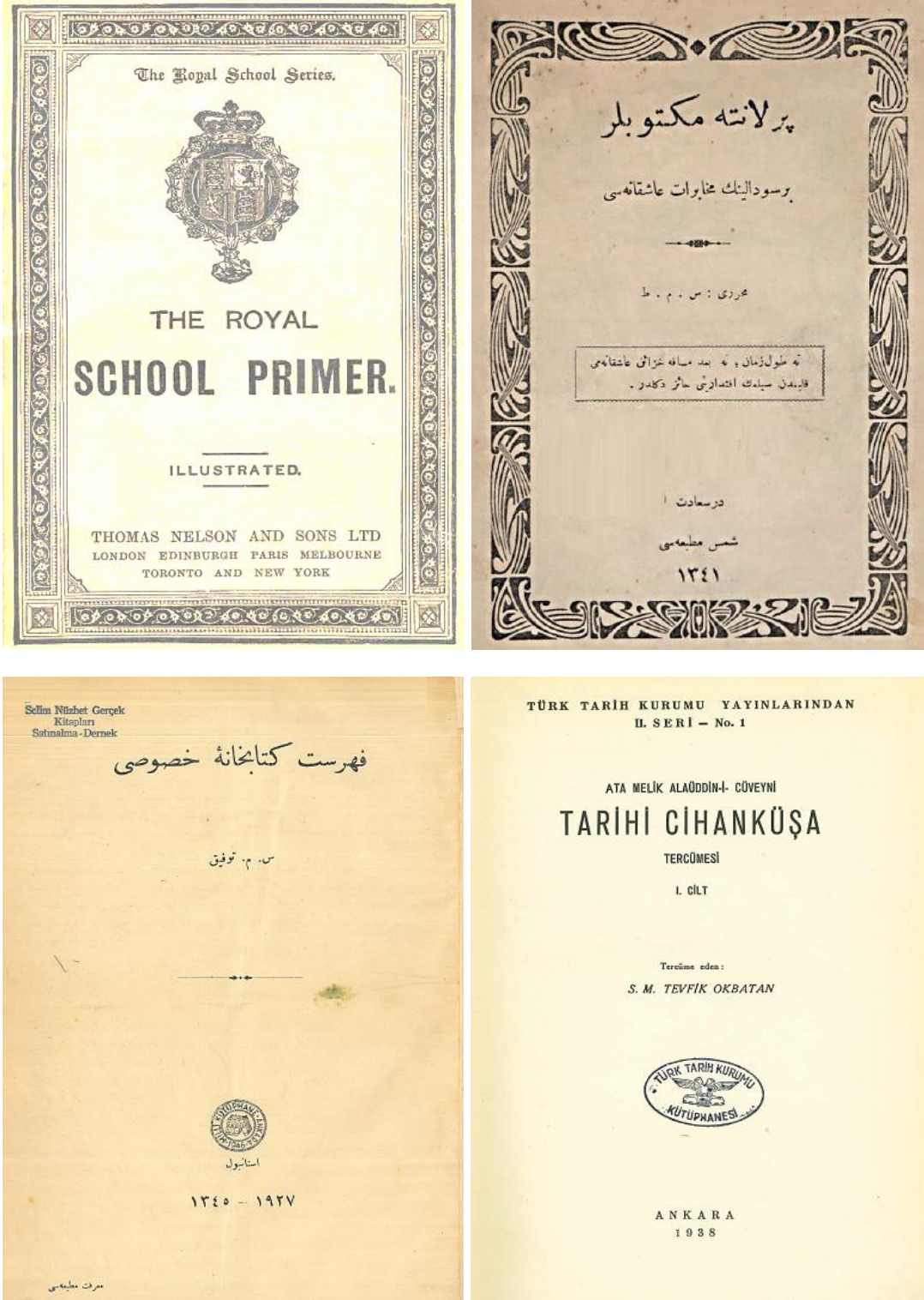

TURK TARIH KURUMU YAYINLARINDAN I. SERI - No. 1

ATA MELIK ALAODDIN- - COVEYWI

\section{TARIHI CIHANKÜSA}

TERCOMES|

1. ClLT

Terceiese edes:

S. M. TEVFIK OKBATAN

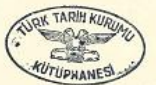

A $N$ K A R A

1938 